\title{
Concepções de administração e administrador em tempos de capitalismo flexível: uma abordagem crítica
}

\author{
Conceptions of management and manager in times of flexible capitalism: a critical \\ approach
}

\author{
Ana Cristina Batista-dos-Santos ${ }^{1}$ \\ José Arimatés de Oliveira ${ }^{2}$
}

\begin{abstract}
Resumo
O texto socializa os resultados de uma pesquisa cujo objetivo foi compreender criticamente as concepções de Administração e Administrador em tempos de capitalismo flexível. A referência epistemológica da pesquisa é a Teoria Crítica frankfurtiana, fundamentada em três pares categóricos dialéticos: história-naturalização, práxis social-sistema, e alienação-emancipação. A literatura prevalente da área foi revisada no tocante aos conceitos em estudo. Metodologicamente, foi realizada uma pesquisa integralmente qualitativa, com uso de três tipos de entrevistas: entrevista narrativa com história de vida; entrevista com elementos-estímulo; e entrevista narrativa ficcional. Para compreensão das narrativas, utilizou-se a técnica de análise hermenêutico-dialética. Os resultados indicam o predomínio da concepção pragmática-instrumental, no tocante à Administração, pela qual ela continua a ser pensada e discursada como uma ação tecnológica e teleológica, que utiliza saberes múltiplos e aprendizagens cambiantes como meios para alcance das finalidades do contexto organizacional mutante. Quanto ao Administrador, há a emergência da concepção estética para apresentá-lo. Por essa concepção, há a migração do histórico estereótipo do Administrador controlador e vigilante para a representação do Administrador como profissional performático. O segundo resultado, que se apresenta como o mais relevante em relação ao Administrador, é o da fuga da profissão.
\end{abstract}

Palavras-chave: Administração. Administrador. Capitalismo Flexível. Teoria Crítica.

\begin{abstract}
The text is backed up by a field research whose goal was to critically comprehend the conceptions of the management field about the Management and the Manager, in times of flexible capitalism. Epistemologically, the research was conducted by the Frankfurtian critical perspective, based on three categorical dialectical pairs: (i) history versus naturalization; (ii) social praxis versus system; (iii) alienation versus emancipation. The mainstream literature of the Management area was revised. Methodologically, a fully qualitative research was carried out using three types of surveys: (i) narrative survey with life story; (ii) a survey with stimuli elements; and (iii) fictional narrative surveys. For the sake of interpretation and comprehension of the narratives, a hermeneutical-dialectical analysis technique was used. The results indicate the predominance of the pragmatical-instrumental conception regarding Management, through which it continues to be thought and discussed as a technological and teleological action, that uses multiple knowledge and shifting learning as a means of reaching the goals of the changing organizational context. Regarding the Manager, there is the emergence of the aesthetical conception to introduce it. Through this conception, there is the migration from the
\end{abstract}

Artigo submetido em 17 de maio de 2014 e aceito para publicação em 13 de outubro de 2014.

DOI: http://dx.doi.org/10.1590/1679-395123042

${ }^{1}$ Doutora em Administração pela Universidade Federal do Rio Grande do Norte; Professora assistente na Universidade Estadual do Ceará. Endereço: Av. Dr. Silas Munguba, 1700, Campus do Itaperi, CEP 60.714.903, Fortaleza - CE, Brasil. E-mail: ana.batista@uece.br

2 Doutor em Administração pela Fundação Getulio Vargas/EAESP; Professor adjunto na Universidade Federal do Rio Grande do Norte. Endereço: Campus Universitário Lagoa Nova, Edifício do CCSA - 10 andar - CEP 59078-970, Natal - RN, Brasil. Email: arimates@gmail.com 
historic stereotype of the controlling and watchful Manager to the representation of the Manager as a performance professional. The second result, the most relevant with respect to the Manager, is that of the escape from the profession.

Keywords: Management. Manager. Flexible Capitalism. Critical Theory.

\section{Introdução}

Embora ainda minoritárias, as pesquisas críticas no campo da Administração têm ganhado espaço. Isso é exemplificado pelo surgimento e crescimento do movimento Critical Management Studies, no contexto internacional (ALVENSON e DEETZ, 1998), pela criação de linhas temáticas para trabalhos que adotam uma perspectiva crítica em eventos brasileiros de referência, como os encontros da Associação Nacional dos Cursos de Pós-graduação em Administração (ANPAD), ou, ainda, pela identificação de mais de uma geração de autores socializando trabalhos de cunho crítico na Administração, no contexto brasileiro. Dentre esses autores, podemos citar: Maurício Tragtenberg, na perspectiva marxista libertária, e Alberto Guerreiro Ramos na perspectiva fenomenológica; eles se constituem nos precursores dos estudos críticos em Administração no Brasil, bem como Fernando Cláudio Prestes Motta, José Henrique de Faria e Fernando Coutinho Garcia, representando a primeira geração na linha tragtenberguiana, e autores contemporâneos como Ana Paula Paes de Paula, Francis K. Meneghetti, Maria Ceci Araújo Misoczky, dentre outros.

A despeito dos frequentes debates sobre a falta de consenso quanto ao conceito de crítica para os críticos (PAULA, 2008), observa-se certa confluência temática nos trabalhos: poder, controle, dominação, disciplina e ideologia, colocados como crítica ao capital; e emancipação, autonomia e mudança social, apontadas como possibilidades para o trabalhador. Em geral, os textos trazem como pano de fundo a dialética capitaltrabalho, e, não menos frequentemente, narram a administração como agente do capital, presos ao discurso da sua culpabilização por tomá-la como promotora dos males que assolam o trabalho.

A pesquisa que fundamenta este trabalho identificou e buscou trabalhar criticamente uma lacuna: a questão "ontológica" (não respondida) da administração - O que é Administração? -, questão essa imersa no silêncio acrítico sobre a administração enquanto trabalho e sobre o administrador enquanto trabalhador, tanto por parte do mainstream, quanto por parte da crítica. Mesmo concordando que predomine, historicamente, uma sujeição acrítica da administração ao capital, este trabalho propõe que essa questão fundamental tem sido mal respondida. Parte-se, aqui, da compreensão da administração como trabalho e do administrador, profissional assalariado, como integrante da classe-que-vive-do-trabalho (ANTUNES, 2003), classe nãoproprietária. A administração inscreve-se como processo de trabalho na concretude das relações de produção, sendo, como afirma Braverman (1987, p. 228): "um processo de trabalho rigorosamente análogo ao processo de produção, embora ele não produza artigo algum que não seja a operação e coordenação da empresa. [Portanto], examinar a gerência significa também examinar esse processo de trabalho que contém as mesmas relações antagônicas contidas no processo de produção".

A pergunta apenas aparentemente simples - O que é Administração? -, que vem sendo respondida indefinidamente como ciência, arte, tecnologia, fenômeno político ou, de maneira simplista, como sendo aquilo que os gerentes fazem, quando não silenciada, desvela-se, então, como o problema conceitual da Administração, problema de um campo com crise de identidade possivelmente devido a sua sujeição acrítica aos movimentos do capitalismo. Esse foi o tema escolhido para estudo: aprofundar-se na questão "ontológica" da Administração, considerando o contexto sócio-histórico do capitalismo flexível. O objetivo geral da pesquisa foi compreender criticamente as concepções do campo administrativo sobre a Administração e o Administrador, em tempos de capitalismo flexível, operacionalizado pelos seguintes objetivos específicos: (i) identificar as concepções do campo administrativo sobre a Administração; (ii) identificar as concepções do campo administrativo sobre o Administrador; (iii) discutir, a partir de uma abordagem crítica, os resultados dos objetivos anteriores. 


\section{Concepções de Administração e Administrador na Literatura Prevalente}

Diversos autores podem ser considerados integrantes do mainstream da administração. Este texto socializa uma síntese de concepções identificadas em sete desses autores, por entender que foram ou são propagadores do pensamento administrativo em três momentos da recente história da administração, esta amalgamada com três fases do capitalismo: capitalismo familiar, capitalismo burocrático e capitalismo flexível (BOLTANSKI e CHIAPELO, 2009).

Taylor (1986) e Fayol (1989) representam o primeiro momento de sistematização da matéria administrativa, imersos historicamente na transição de um capitalismo tipicamente familiar para um capitalismo burocrático. Em seguida, através de Drucker (1975), são acessadas as concepções de administração e administrador na fase de oponência do capitalismo burocrático, seguindo o anúncio da lógica flexível. O último bloco de autores, composto por Deming (1990), Ohno (1997), Champy (1995), e Mintzberg (2009), representa as concepções atualmente dominantes sobre o capitalismo em sua fase flexível. Os Quadros 1 e 2 sintetizam os temas e concepções identificados na literatura consultada:

Quadro 1

Síntese das concepções da literatura (Administração)

\begin{tabular}{|c|c|c|c|c|}
\hline $\begin{array}{l}\text { Concepção } \\
\text { sistêmica }\end{array}$ & $\begin{array}{l}\text { Concepção } \\
\text { pragmática }\end{array}$ & $\begin{array}{c}\text { Concepção } \\
\text { comportamental }\end{array}$ & $\begin{array}{l}\text { Concepção } \\
\text { filosófico- } \\
\text { doutrinária }\end{array}$ & $\begin{array}{l}\text { Concepção } \\
\text { político- } \\
\text { ideológica }\end{array}$ \\
\hline $\begin{array}{l}\text { Função } \\
\text { Órgão } \\
\text { Sistema } \\
\text { totalizante } \\
\text { Cérebro } \\
\text { Sistema de } \\
\text { melhoria contínua }\end{array}$ & $\begin{array}{l}\text { Atividades } \\
\text { Desempenho } \\
\text { Prática } \\
\text { Prática situacional } \\
\text { Ação } \\
\text { transformadora } \\
\text { "Ciência" }\end{array}$ & $\begin{array}{l}\text { Liderança } \\
\text { Força } \\
\text { Responsabilidade } \\
\text { Posição }\end{array}$ & $\begin{array}{l}\text { Filosofia } \\
\text { Doutrina }\end{array}$ & $\begin{array}{l}\text { Instituição social } \\
\text { "Ciência" }\end{array}$ \\
\hline $\begin{array}{l}\text { Fayol } \\
\text { Drucker } \\
\text { Deming } \\
\text { Ohno }\end{array}$ & $\begin{array}{l}\text { Taylor } \\
\text { Drucker } \\
\text { Deming } \\
\text { Mintzberg }\end{array}$ & $\begin{array}{l}\text { Drucker } \\
\text { Champy }\end{array}$ & $\begin{array}{l}\text { Taylor } \\
\text { Fayol }\end{array}$ & $\begin{array}{l}\text { Taylor } \\
\text { Drucker }\end{array}$ \\
\hline
\end{tabular}

Fonte: Quadro elaborado pelos autores (2013).

Quadro 2

Síntese das concepções da literatura (Administrador)

\begin{tabular}{|c|c|c|c|c|}
\hline $\begin{array}{l}\text { Concepção } \\
\text { sistêmica }\end{array}$ & $\begin{array}{l}\text { Concepção } \\
\text { pragmática }\end{array}$ & $\begin{array}{c}\text { Concepção } \\
\text { comportamental }\end{array}$ & $\begin{array}{l}\text { Concepção } \\
\text { filosófico- } \\
\text { doutrinária }\end{array}$ & $\begin{array}{c}\text { Concepção } \\
\text { político- } \\
\text { ideológica }\end{array}$ \\
\hline $\begin{array}{l}\text { Planejador } \\
\text { Regente } \\
\text { Otimizador do } \\
\text { sistema }\end{array}$ & $\begin{array}{l}\text { Fazedor } \\
\text { Artesão } \\
\text { Treinador } \\
\text { Professor }\end{array}$ & $\begin{array}{l}\text { Modelo } \\
\text { Cooperador } \\
\text { Responsável } \\
\text { Mobilizador da }\end{array}$ & $\begin{array}{l}\text { Discipulador } \\
\text { Conselheiro } \\
\text { Educador } \\
\text { Inculcador de } \\
\text { valores }\end{array}$ & $\begin{array}{l}\text { Cooptador } \\
\text { Aprendiz }\end{array}$ \\
\hline
\end{tabular}




\begin{tabular}{|c|c|c|c|c|}
\hline & $\begin{array}{l}\text { (demonstrador) } \\
\text { Frenético } \\
\text { Eliminador de } \\
\text { desperdícios }\end{array}$ & $\begin{array}{l}\text { mudança } \\
\text { Líder visionário } \\
\text { Comunicador } \\
\text { Herói }\end{array}$ & & Cont. Quadro 2 \\
\hline $\begin{array}{l}\text { Concepção } \\
\text { sistêmica }\end{array}$ & $\begin{array}{l}\text { Concepção } \\
\text { pragmática }\end{array}$ & $\begin{array}{c}\text { Concepção } \\
\text { comportamental }\end{array}$ & $\begin{array}{l}\text { Concepção } \\
\text { filosófico- } \\
\text { doutrinária }\end{array}$ & $\begin{array}{l}\text { Concepção } \\
\text { político- } \\
\text { ideológica }\end{array}$ \\
\hline Taylor & Taylor & Taylor & Deming & Taylor \\
\hline Deming & $\begin{array}{l}\text { Drucker } \\
\text { Ohno } \\
\text { Mintzberg }\end{array}$ & $\begin{array}{l}\text { Fayol } \\
\text { Deming } \\
\text { Drucker } \\
\text { Ohno } \\
\text { Champy } \\
\text { Mintzberg }\end{array}$ & Champy & Deming \\
\hline
\end{tabular}

Fonte: Quadro elaborado pelos autores (2013).

A linguagem sistêmica é recorrente na totalidade dos autores estudados. Contudo, a concepção sistêmica é diretamente assumida em Fayol (1989), Drucker (1975), Ohno (1997) e Deming (1990). Essa concepção emerge predominantemente através de um discurso metafórico que toma a Administração como uma função ou órgão específico, que integra uma organização entendida como organismo vivo, exemplificando a prática corrente no campo administrativo de praticar a transferência inadequada de conceitos (RAMOS, 1981). Por vezes, a Administração é apresentada como sendo o próprio sistema, preferencialmente, um sistema total, global. Nessa categoria de concepção, o Administrador tende a ser identificado como planejador, regente e otimizador do sistema.

A concepção pragmática emerge de maneira bastante expressiva na quase totalidade dos autores examinados. Ela se torna identificável através de um discurso que, ao tentar definir a Administração, utiliza com frequência termos como ação, prática, atividades, tarefas, e desempenho. Por vezes, essa ação - ou prática - é adjetivada como transformadora e situacional, por exemplo, dando os contornos com que cada autor vai qualificando a Administração como algo pragmático. O tema "ciência" também integra as concepções pragmáticas, apenas no sentido evocado por Mintzberg (2009), de que algum resultado da ciência é pragmaticamente utilizado pela Administração. Os autores que concebem, predominantemente, a Administração de maneira pragmática são: Taylor (1986), Drucker (1975), Deming (1990), e Mintzberg (2009). O Administrador, nessa concepção, é identificado como um permanente fazedor, é metaforizado como artesão, como treinador, e ainda, como professor demonstrador; também é apresentado como um indivíduo frenético e com uma obsessão pela eliminação de desperdícios.

A concepção comportamental, por sua vez, desvela-se no discurso da literatura principalmente através do tema liderança, mas também através de dimensões como responsabilidade, força e posição, pelas quais a Administração deve "se comportar" como: (i) tendo a responsabilidade por algo; (ii) sendo uma força em si mesma; ou (iii) aquela que deve atuar a partir da posição que lhe é inerente. Os autores que, em geral, transitam nesse universo semântico para conceber a Administração são: Drucker (1975), Deming (1990), Champy (1995), e Mintzberg (2009). Por essa concepção, o Administrador se comporta como modelo, cooperador, mobilizador da mudança, é metaforizado como herói, mas, principalmente, é narrado como líder e como responsável pelo que acontece nas organizações.

Surpreendentemente, a concepção filosófico-doutrinária emerge de maneira pontual somente em autores considerados expoentes da Administração tradicional: Taylor (1986) e Fayol (1989). Taylor (1986), apesar 
de qualificar como científico o sistema de Administração que propunha, apresenta a Administração como uma nova filosofia. Fayol (1989) entendia a Administração como a doutrina que faltava ao mundo dos negócios. Autores mais contemporâneos como Deming (1990) e Champy (1995) assumem essa concepção filosófico-doutrinária através de suas representações de Administrador, apresentando este último através de metáforas como discipulador, conselheiro, educador e inculcador de valores.

Já a concepção político-ideológica é aqui compreendida como identificável no discurso de Drucker (1975), quando este afirma de maneira categórica e prescritiva que a Administração é uma instituição social, a despeito de qualquer debate sociológico ou consenso social sobre tal "enquadramento"; e, também, no discurso taylorista, que inaugura a definição da Administração como ciência, sem igualmente ter havido qualquer consenso acadêmico sobre a questão, exemplificando concepções que se impõem pelo discurso, independentemente de existirem ou não fundamentos para admiti-las ao nível do concreto. O Administrador, nessa concepção, desvela-se, em Taylor (1986), como cooptador de conhecimento; e como aprendiz, no discurso da qualidade; ambos relacionados ao conhecimento como "matéria-prima" da "Administraçãociência".

\section{Fundamentos Epistemológicos e Desenho da Pesquisa}

A crítica, em sentido frankfurtiano, especialmente a oriunda das reflexões da primeira geração da Escola de Frankfurt, é aquela resultante do exercício da auto-reflexividade, exercício que impõe colocar os juízos e conceitos prévios em suspensão para interrogar-se sobre si, o outro, o mundo, visando compreender, sempre provisoriamente, os fenômenos sociais. Oposta que é à lógica formal, causal, linear, própria à teoria tradicional positivista, a Teoria Crítica (TC), por sua vez, entende a lógica dialética como constituinte da realidade, sendo, portanto, a que melhor daria conta de compreender essa mesma realidade (HORKHEIMER, 1980; ADORNO, 1980; 1986). Pautar-se na dialética para empreender uma práxis de pesquisa crítica exige adequações metodológicas, buscando apreender essa tensão dialética constituinte dos fenômenos. Este trabalho se fundamentou nas contribuições de Adorno (1980), Horkheimer (1980), e os dois juntos (ADORNO e HORKHEIMER, 1985), para eleger categorias epistemológicas críticas norteadoras do trabalho de campo, a saber: naturalização-história; sistema-práxis social; e alienação/dominação-emancipação.

Uma pesquisa de natureza integralmente qualitativa foi delineada, isto é, aquela fruto da interação entre dados qualitativos e análise qualitativa dos dados (DESLAURIERS e KÉRISIT, 2008), utilizando-se a entrevista como técnica de coleta que leva à emergência de narrativas situadas no interstício homem-mundo, que se abrem como textos passíveis de compreensão. Foram utilizados tipos variados: (i) entrevista narrativa com história de vida; (ii) entrevista com elementos-estímulo; e (iii) entrevistas narrativas ficcionais. Essas são adaptações de múltiplas técnicas, configurando um mix metodológico favorável à manifestação da tensão dialética própria às dimensões epistemológicas norteadoras.

Quanto ao primeiro tipo de entrevista, investiu-se na dimensão narrativa como fundamento para emergência das concepções de administração e administrador. Para Jovchelovitch e Bauer (2002), em geral, as entrevistas narrativas são uma forma de entrevista não estruturada e de profundidade, que tem em vista a reconstrução discursiva de algo anteriormente vivido pelo sujeito, visando ultrapassar o clássico modelo pergunta-resposta. Nessa entrevista, tinha-se como alvo o discurso do outro em sua rememoração do vivido (HAGUETTE, 2001). Conforme os roteiros (Apêndice: Quadros 5, 6, 7), buscou-se evocar uma narrativa histórica do sujeito, na qual os objetos em estudo pudessem ser por ele evocados no cenário da sua existência. Partiu-se do entendimento de Adorno (1980) de que devemos sempre considerar a constituição histórica dos fenômenos se pretendemos compreendê-los, ressaltando a importância das dimensões objetivas (economia, sociedade, política) e subjetivas (momentos psicológicos), que captem o entrelaçamento entre o individual e o social. Importava saber, por exemplo, sobre a história de vida dos sujeitos à época da escolha do curso de administração, e o que os levou, naquele momento, a optar pela área. Que concepções tinham, àquela época, sobre a administração e o profissional administrador? Como tais concepções se entrelaçavam com sua história de vida, com o mundo em geral e o organizacional, em particular? 
$\mathrm{Na}$ segunda entrevista, o elemento-estímulo foi o recurso incentivador e norteador da fala. Elementoestímulo é "algo" (pergunta, afirmação, proposição) que se apresenta ao entrevistado como uma proposta suficientemente ampla, mas necessariamente focal, servindo de eixo a uma entrevista (ALBANDESMOREIRA, 2002). Originalmente, o autor falava de questão-estímulo. Nessa pesquisa, editou-se a expressão para elemento-estímulo tendo em vista que são múltiplas as possibilidades de estímulos, e não apenas uma pergunta. O elemento-estímulo possibilita ao pesquisador obter o máximo de informação multidisciplinar relevante e necessária à pesquisa, sem transformar a entrevista em interrogatório. Usando variados elementos que estimulem o entrevistado a discorrer sobre a temática central, o pesquisador provê condições de exame do tema em termos de práticas e de experiências subjetivas, de afetos e conhecimentos, de teorias e realizações mais próximas da realidade. O elemento-estímulo foi a palavra ADMINISTRAÇÃO, colocada em folha impressa em estilo cartaz, diante do entrevistado, solicitando que ele falasse livremente sobre ela.

Dentre as inúmeras possibilidades de conteúdos que poderiam surgir, tinha-se especialmente em consideração, quando da proposta desse segundo tipo de entrevista, a possibilidade de emergência das concepções de administração e administrador envoltas em conteúdos ligados à tensão dialética da práxis social-sistema, devido à recorrente tendência de professores, alunos e administradores reproduzirem o discurso sistêmico dos livros e textos da área, no qual, para a administração, é delegada a tarefa de garantir a funcionalidade de uma organização-sistema, negando não só aos subordinados, mas também ao administrador, as possibilidades de uma espontaneidade própria à práxis social autêntica. Essa proposta metodológica baseou-se na perspectiva epistemológica de Horkheimer (1980) que denunciava a postura sistêmica da teoria tradicional que toma a realidade social como formada por elementos, organizados em uma lógica harmônica que elimina a contradição, e corroborada por Adorno (1980), para quem essa visão harmonizadora mecânica se constitui na colocação de um véu que escamoteia os antagonismos inscritos em sua base material, que é a práxis.

O terceiro tipo foi a entrevista narrativa ficcional, combinação e adaptação das técnicas da entrevista narrativa tradicional (JOVCHELOVITCH e BAUER, 2002) e da entrevista ficcional (ALBANDESMOREIRA, 2002). Jovchelovitch e Bauer (2002) discutem a relação entre narrativa, realidade e representação, e entendem que as narrativas não devem ser consideradas como espelhos da realidade, devendo-se atentar para sua dimensão expressiva, aquela que guarda relação com as representações do contador de história: "o que dizer de narrativas que estão claramente separadas da realidade dos acontecimentos?" (idem, p. 109). O que elas dizem sobre o que/como os narradores pensam? Assim, com a entrevista narrativa ficcional, buscou-se evocar narrativas "descoladas" dos eventos fáticos, porém plenamente imbricadas nas representações dos sujeitos de pesquisa. Com os roteiros (script) propostos (Apêndice, Quadros 8 e 9), almejava-se, principalmente, "acessar" tais representações, especialmente as relacionadas aos construtos administração e administrador. Entretanto, ensejava-se, também, com o "descolamento" do real que a ficcional possibilita, identificar possíveis conteúdos que expressassem a tensão dialética alienação/dominação-emancipação. Especialmente no tocante as suas narrativas fictícias de carreiras, esperava-se ver em que situações profissionais eles colocariam o administrador. Seria no recorrente lugar de mediação entre capital e trabalho? Se não neste, em qual seria?

Com esse desenho de pesquisa, foi-se ao campo. Ao todo, foram entrevistados 7 sujeitos. No grupo de docentes, duas professoras graduadas em Administração, com mestrado na área, ensinando atualmente em universidades públicas, uma federal e outra estadual (Dora e Dani). Entre os alunos entrevistados, um é do sexo masculino (Dan), iniciando o curso de Administração, cursando o segundo semestre à época das entrevistas. O outro aluno é do sexo feminino (Mari), à época concluindo o curso. Ambos estudam em uma universidade pública federal. Dentre os administradores, dois são do sexo masculino (Fred e Max) e um do sexo feminino (Lia). Os dois são administradores e donos do próprio negócio. A última é uma administradora pública. Ao todo, a pesquisa de campo resultou em aproximadamente 12 horas de entrevistas. As entrevistas foram integralmente transcritas, resultando em um arquivo de registro contendo 114 páginas.

A técnica de análise qualitativa utilizada foi a hermenêutico-dialética. Minayo $(2002 ; 2004)$ é a pesquisadora que tem proposto tal técnica, no estágio atual da pesquisa qualitativa brasileira, desde o seu campo de pesquisa, a área da saúde. Pesquisadores de outros campos disciplinares têm adotado o mesmo caminho 
analítico, como Oliveira (2001), na área de educação. Mais recentemente, também indicaram o uso da técnica, pesquisadores qualitativos da área de Administração que trabalham segundo a perspectiva crítica, como Bicalho (2009), Bicalho e Paes de Paula (2009) e Cardoso (2010).

Minayo (2004) propôs essa tipologia de análise ancorada nas proposições de Stein (1987) sobre questões que envolvem o emprego da dialética e da hermenêutica. Levando-se em conta as origens epistemológicas diversas, a hermenêutica e a dialética constituem "dois caminhos através dos quais o debate atual sobre a questão do método se desenvolve numa esfera que transcende a fragmentação dos procedimentos científicos em geral" (STEIN, 1987, p. 99), perspectiva que se mostra alinhada aos movimentos de vanguarda da histórica Escola de Frankfurt, cujo "trabalho tem sido hibridizado e amalgamado com outras tendências teóricas" (JAY, 2008, p. 16). Para Stein (1987), a conjunção da hermenêutica com a dialética constitui-se como método apropriado para compreensão do real, argumento que Minayo $(2002 ; 2004)$ acolhe e traduz em termos de utilização da análise hermenêutico-dialética como "caminho do pensamento", mais do que em termos de procedimentos operacionais pormenorizados. Para a autora, a análise hermenêutico-dialética visa transcender os aspectos meramente procedimentais associados a técnicas, como a análise de conteúdo e análise de discurso, bem como almeja evitar os problemas epistemológicos a elas associados.

A análise hermenêutico-dialética preserva da hermenêutica a possibilidade de interpretação dos sentidos que os sujeitos elaboram em seus discursos, estes tratados como textos a serem interpretados, e investe na possibilidade que a dialética fornece de compreender tais discursos em face das contradições e da totalidade da práxis social: "enquanto a hermenêutica penetra no seu tempo e através da compreensão procura atingir o sentido do texto, a crítica dialética se dirige contra seu tempo. Ela enfatiza a diferença, o contraste, o dissenso e a ruptura de sentido." (MINAYO, 2004, p. 227). Tal técnica se operacionaliza, portanto, pelo constante movimento pendular entre interioridade e exterioridade, teoria e práxis, dado e mundo, indivíduo e sociedade. A análise não se restringe ao "momento hermenêutico", de diálogo com as falas dos sujeitos, estas tomadas como texto a ser interpretado "em si mesmo"; este momento integra uma dinâmica maior porque constituinte da própria fala, que é o "movimento dialético", pelo qual se considera essa fala como inscrita no mundo, na totalidade, na práxis de uma determinada sociedade, em toda sua dinâmica, complexidade e contradições, pois "não há nada, mas nada mesmo, sob o sol que, por ser mediado pela inteligência humana e pelo pensamento humano, não seja ao mesmo tempo também mediado socialmente" (ADORNO, 2008, p. 72). Portanto, essas falas emergem em contextos (culturais) específicos, que lhes servem de mediação, pois como afirma Gomes (1996, p. 7): "[na técnica hermenêutica-dialética] a fala dos atores sociais é situada em seu contexto para melhor ser compreendida. Essa compreensão tem, como ponto de partida, o interior da fala. E, como ponto de chegada, o campo da especificidade histórica e totalizante que produz a fala" (GOMES, 1996, p. 7).

Para empreender o processo analítico-compreensivo, foram considerados os contextos em que os sujeitos se inscrevem em duas perspectivas, ou aproximações: os contextos imediatos e os mediatos (Figura 1). Os contextos imediatos correspondem aos espaços em que as existências dos sujeitos se passam, ou os que eles projetam para suas vivências futuras, nos quais suas vidas adquirem um sentido, e a partir dos quais manifestam a condição de seres sócio-históricos. Nessa pesquisa, os contextos imediatos considerados foram: (i) a história de vida individual; (ii) a universidade; e (iii) as organizações de trabalho. Os contextos mediatos são a própria história em geral, sociedade e economia, em que todos estamos implicados.

A análise se deu em um movimento de contato com as falas em duas perspectivas: uma descritiva e outra exploratória; e em dois momentos: o primeiro em que as falas dos sujeitos eram analisados por grupos (professores, alunos, administradores) e o segundo momento em que se discutiu a narrativa totalizante. A instância descritiva disse respeito à identificação das opiniões, motivos e juízos dos entrevistados sobre três dimensões: (i) os contextos imediatos (história de vida pessoal, universidade e organizações de trabalho); (ii) suas escolhas (curso e área de Administração); (iii) seus destinos profissionais (carreira futura). Essas foram consideradas como dimensões a priori, e como pano de fundo do objeto de estudo: as concepções de Administração e Administrador. A instância exploratória, por sua vez, foi a que permitiu a identificação de temas emergentes do campo empírico, ou dimensões a posteriori, aquelas que esposam mais explicitamente suas representações dos construtos em estudo. Esses temas foram reunidos em grupos temáticos. 
Figura 1

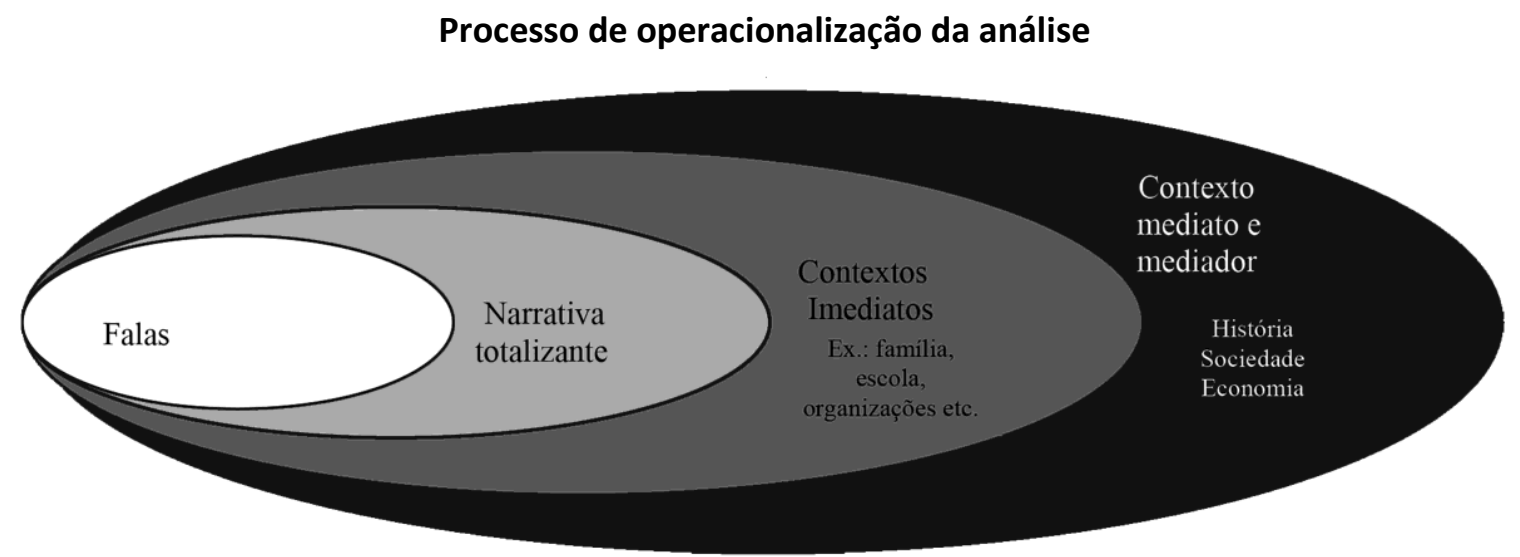

Fonte: Elaborado pelos autores.

Para auxiliar na operacionalização do processo interpretativo, optou-se pelo recurso analítico de trabalhar com metáforas para compreensão das concepções que transitam no campo em estudo, especialmente pelo fato de a pesquisa tratar de conceitos. Lakoff e Johnson (2002) defendem a ideia de que muito mais do que um aparato ou adornamento linguístico, a metáfora deve ser entendida como uma expressão (linguística) da forma como os homens pensam, conceitualizam e agem no mundo. Sendo "a essência da metáfora compreender e experienciar uma coisa em termos de outra" (LAKOFF e JOHNSON, 2002, p. 48), a sistematicidade metafórica presente em um discurso tanto realça, quanto encobre conteúdos e suas contradições. Entendendo que os processos de pensamento são, em grande parte, metafóricos porque o sistema conceitual humano é metaforicamente estruturado e definido, Lakoff e Johnson (idem, ibidem) argumentam que "um conceito metafórico estrutura o que fazemos, assim como a maneira pela qual compreendemos o que fazemos". É, portanto, a metáfora, um evento linguístico que sintetiza a tríade linguagem-pensamento-ação. Esse caminho analítico contribuiu, especialmente, para realizar a discussão dialética dos resultados, pois o exame do discurso metafórico oferece condições interessantes para lidar com as ambiguidades e as contradições emergentes nos discursos.

\section{Análise e Discussão dos Resultados}

Apenas por razões de espaço, as falas dos sujeitos não são literalmente e integralmente divulgadas neste texto, trabalhando-se, nesta seção, com as sínteses interpretativas sobre as mesmas. Da leitura analítica da dimensão de contextos (escolhas, destinos, universidade e organizações), previamente escolhida para exame, diversos temas foram identificados e sintetizados no Quadro 3. Os temas emergentes da fase exploratória também foram sintetizados e são apresentados, por grupos de sujeitos, no Quadro 4. Do exame desses temas e grupos tomados como uma totalidade, foi elaborada uma síntese empírica da pesquisa, apresentada sob a denominação de Grupos Temáticos (GTs) (Figura 2). Os GTs congregam as zonas de convergência de sentidos entre os grupos, bem como especificidades ou singularidades qualificadoras da compreensão do todo da narrativa.

O Grupo Temático I apresenta uma tensão que permeia toda a narrativa, independentemente do grupo de sujeitos, cada qual elaborando a questão em seus próprios termos, atravessada por um sentido comum. Tal tensão se refere ao antagonismo expresso nos sentimentos e pensamentos ambivalentes que tanto professores quanto alunos e administradores tendem a nutrir pela Administração, e a tensão envolve: gostar/não gostar, não se convencer/apaixonar-se, reconhecer a importância/temer a concorrência, além da luta por permanente reconhecimento, em uma espécie de dicotomia do tipo "bem versus mal". 
Quadro 3

Síntese de dimensões a priori: contextos

\begin{tabular}{|c|c|c|c|}
\hline \multicolumn{4}{|c|}{ Contextos } \\
\hline \multicolumn{2}{|c|}{ História de vida estudantil e profissional } & \multicolumn{2}{|c|}{ Contextos imediatos } \\
\hline Escolhas & Destinos & Universidade & Organizações \\
\hline $\begin{array}{l}\text { Indefinição } \\
\text { Indecisão } \\
\text { Dúvida } \\
\text { Problema } \\
\text { Não escolha } \\
\text { Segunda opção } \\
\text { Complemento } \\
\text { Questionamento } \\
\text { Paixão } \\
\text { Certeza } \\
\text { Encanto }\end{array}$ & $\begin{array}{l}\text { Formação continuada } \\
\text { Administrador de TI } \\
\text { Gestor de pessoas } \\
\text { Docente } \\
\text { Empreendedor } \\
\text { Concurso público } \\
\text { Gerência de empresa } \\
\text { de grande porte } \\
\text { Gerência de compras } \\
\text { Consultoria }\end{array}$ & $\begin{array}{l}\text { Importância } \\
\text { Valorização social } \\
\text { Depositária do saber } \\
\text { Ressentimento } \\
\text { Formação } \\
\text { Múltiplas } \\
\text { aprendizagens }\end{array}$ & $\begin{array}{l}\text { Empresa } \\
\text { Objetivos } \\
\text { Organismo vivo } \\
\text { Mudanças } \\
\text { Identificação } \\
\text { Pertencimento } \\
\text { Ambiente dinâmico } \\
\text { Necessidades } \\
\text { Formação } \\
\text { Lucro } \\
\text { Inovação } \\
\text { Família } \\
\text { Orquestra } \\
\text { Continente } \\
\text { Múltiplas aprendizagens }\end{array}$ \\
\hline
\end{tabular}

Fonte: Elaborado pelos autores.

Quadro 4

Síntese de temas emergentes, por grupos de sujeitos

\begin{tabular}{|l|l|l|}
\hline \multicolumn{1}{|c|}{ Professores } & \multicolumn{1}{|c|}{ Alunos } & \multicolumn{1}{c|}{ Administradores } \\
\hline Amplitude & Ação (fazer, prática, experiência, & Não gostar \\
Utilidadencia) & Tecnologia & Gostar \\
Concorrência & Abrangência & Atividades sistemáticas \\
Importância/reconhecimento & Desvalorização & Mudanças \\
Saberes e fazeres & Paixão & Perfil \\
Experiência & Visual & Experiência \\
Conhecimento aplicado & Estilo & Aprendizagens \\
Necessidades & Status & \\
Mudanças & & \\
Finalidades & & \\
\hline
\end{tabular}

Fonte: Elaborado pelos autores. 
Figura 2

\section{Síntese da parte empírica da pesquisa (grupos temáticos)}

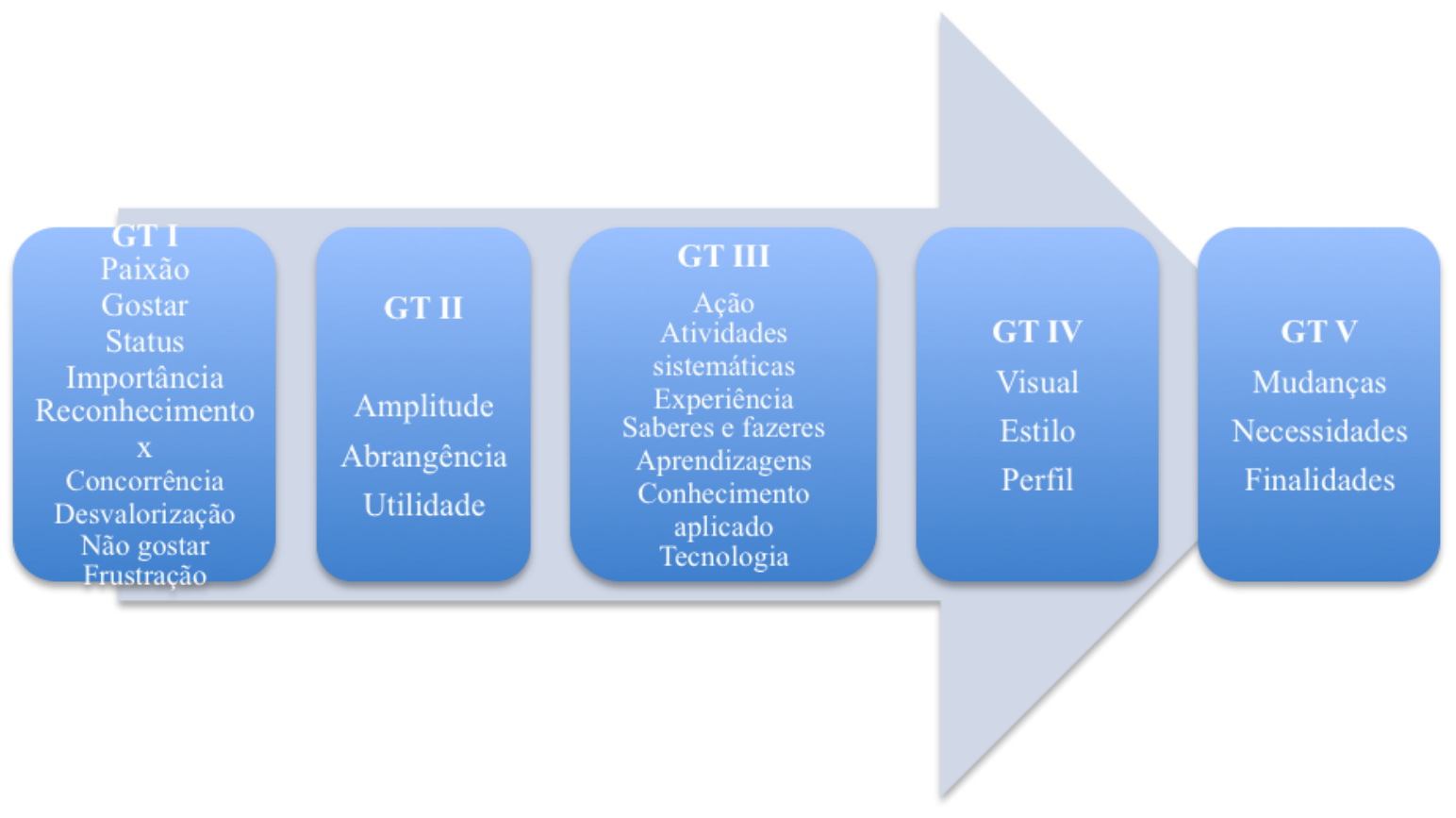

Fonte: Elaborado pelos autores.

Essa tensão se mostra relacionada, na narrativa, aos processos de escolha de curso, às inquietações no decorrer do mesmo, e diante da decisão sobre o exercício da profissão. Quanto às escolhas de curso, nota-se a recorrência de temas como dúvida, incerteza, indefinição; o curso de Administração figurando muitas vezes como uma segunda opção, ou complementando outro curso/área. Em relação aos destinos profissionais, percebe-se que os entrevistados elaboram narrativas alternativas pelas quais ou passam rapidamente pela gestão para depois investirem em outro rumo profissional (principalmente como professores ou empreendedores), ou apontam para um adiamento da prática administrativa em suas vidas.

Nos administradores, há um movimento entre querer e não querer, gostar e não gostar, não ser convencido pelo curso e depois apaixonar-se, que, frequentemente, é traduzido em dúvida na escolha durante e, por vezes, até o final do curso. Esse antagonismo da área pode ser assim sintetizado, no grupo de administradores: em uma mesma área, convivem a lógica do "não gosto", "não sei se quero", "não me convence, logo, desisto"; com a possibilidade do encantamento, da admiração e da paixão, estes advindos da aproximação com a dimensão prática da área.

Entre os alunos, identifica-se que, diante de tal tensão, especificamente a aluna Mari adota três vertentes discursivas: (i) é proativa na crítica à desvalorização social da área; (ii) é silente quanto à falta de valor que ela própria dá a sua formação; (iii) é passiva para viver, em termos profissionais, o que declara ter se tornado uma paixão. Isso permite propor a síntese de que a aluna não consegue elaborar subjetivamente o antagonismo entre a paixão e a desvalorização do objeto da paixão, a Administração, acomodando-a como um sonho, um encanto, ou um adiamento em sua própria existência. Por outro lado, Dan é o mais expressivo em relação à valorização da Administração através do tema status, que ele elabora especialmente relacionando-o ao Administrador, um tipo profissional importante por assumir posições privilegiadas dentro do contexto organizacional.

Entre o grupo de professores, a inquietação com o aspecto negativo da concorrência com outras áreas e da falta de reconhecimento da importância da Administração emerge em contraste com o processo de apaixonar-se durante o curso. As entrevistadas parecem admitir que escolheram uma área não consolidada quanto ao reconhecimento social e com permanente incerteza em relação ao exercício profissional, dada a 
concorrência. Assim, elas tomam a luta pelo reconhecimento como sua, nutrindo a esperança de que, embora seja uma área com dificuldades, tem possibilidades de melhoria. Identificar nesse grupo de sujeitos uma não escolha inicial da área de Administração, transmutada posteriormente em uma opção apaixonante e solucionadora de conflitos pessoais, foi algo relevante. Ademais, a procura pela resposta ao que fez essa paixão nascer e se desenvolver, mesmo sendo fruto de uma não escolha consciente, também apontou caminhos de compreensão quanto à "natureza" da Administração para estes sujeitos, os quais respondem com conteúdos ligados ao segundo grupo temático, adiante discutido. Elas, as professoras, como que respondem, dizendo: "me apaixonei porque ela é suficientemente ampla e útil, podendo me apontar várias possibilidades futuras, em termos de carreira como Administrador e, mesmo que por alguma razão, tal encarreiramento não se efetive, não terei perdido tempo, pois a Administração me será útil para tudo, até para "gerência da vida pessoal". Essa racionalização ecoa também nos dois outros grupos. Uma síntese possível sobre tal interpretação é que as professoras acomodam discursivamente o fato original de não terem escolhido Administração, através de um processo de racionalização afetiva e utilitária, pelo qual a Administração se transforma em um objeto alvo de paixão e cuja utilidade generalizada, dada a amplitude da mesma, justifica a permanência no curso, independentemente de uma carreira futura como Administrador.

Esse primeiro grupo temático, associado às dimensões de escolha de curso e destinos profissionais, suscita discussões teóricas e históricas interessantes. Um diálogo teórico possível sobre esse cenário antagônico de otimismo/pessimismo, possibilidades/adiamentos, paixão/rejeição, dá-se com dois tipos de literatura, historicamente bem situados. De um lado, literaturas que apregoavam ou identificavam com reservas uma supervalorização da gerência, correspondente aos anos gloriosos do capitalismo burocrático. Evidencia-se essa supervalorização em diversos autores, com variadas perspectivas e localizações geográficas, como, por exemplo, no contexto anglo-saxão: o capitalismo gerencial (CHANDLER, 1984), administradores como representantes do topo da hierarquia dos colarinhos-brancos (MILLS, 1979), o boom administrativo (DRUCKER, 1975) e, no contexto brasileiro, um clamor por espaço e valorização dos administradores profissionais em face da industrialização do país (PEREIRA, 1966; CASTRO, 1974), ou a emergência de uma categoria profissional a serviço dos interesses do capital (COVRE, 1982). Por outro lado, em uma época mais recente, identifica-se uma literatura que lança luz sobre o mal estar ou desvalorização da gerência, especialmente a intermediária (BITTENCOURT NETO, 2004), a responsabilização da Administração pelos problemas empresariais de baixo crescimento (DEMING, 1990), a recusa aos termos manager (BROCKLEHURST, GREY e STURDY, 2009) ou cadre (BOLTANSKI e CHIAPELLO, 2009), o declínio ou morte do management (GREY, 1999), e, ainda, uma flutuação no seu status com diminuição das recompensas materiais e simbólicas (BROCKLEHURST, GREY e STURDY, 2009).

A narrativa dos entrevistados, então, parece situar-se no interstício dessas duas visões ou dessas duas épocas, e remete ao alerta de Grey (1999) de que as condições do trabalho gerencial não são e nunca foram uma questão homogênea. Ao considerar, por exemplo, as ideias de Drucker (1975), percebe-se a mudança de perspectiva em relação à valorização da função gerencial, ou ao que ele chamava de boom administrativo, fenômeno que, para ele, como todo boom, chegaria ao seu momento de depressão, estando tal depressão associada aos reveses da economia. No momento de crise econômica que sucedeu aos anos gloriosos, Drucker (1975) compartilhava da ideia de redução da "gordura excessiva" dos níveis gerenciais das grandes empresas.

Ao se examinar o lado positivo ou de otimismo da tensão, identificam-se dois temas predominantes que mostram duas inscrições de uma mesma questão. Um é o do sonho/encanto/paixão, e outro é o do status/importância. No primeiro, a narrativa aciona aspectos de natureza pessoal, individual, vinculados ao desejo de um indivíduo, um ser apaixonado e encantado, mais próximo das emoções sentidas em relação ao objeto desejado, do que por algo que, efetivamente, "viva com este objeto". O segundo remete ao lado mais exterior da questão, ou a algo que poderia ser socialmente identificável, isto é, uma importante localização social garantidora de prestígio.

Esse conteúdo da narrativa faz ecoar, mesmo que retrospectivamente, tanto o ideário quanto a concretude da importância da Administração e Administrador na literatura correspondente aos anos gloriosos, do quarto de século após a Segunda Guerra Mundial, no contexto anglo-saxão. Drucker (1975) apresentava a 
Administração como pedra angular e nova instituição social, indispensável à vida em sociedade. Mills (1979) e Chandler (1984) relacionavam tal importância às necessidades da indústria moderna que, do rápido crescimento, demandou a multiplicação das funções de coordenação e controle dentro do novo tipo de organização: a indústria burocratizada. É nessa empresa integrada verticalmente que os "colarinhos-brancos" (MILLS, 1979) têm lugar privilegiado em uma grande hierarquia gerencial (CHANDLER, 1984).

A essa localização, a esse status, corresponde o prestígio, que emergiu nas entrelinhas da narrativa do grupo entrevistado, especialmente nas valorizações que faz dos movimentos ascendentes, e nas atraentes metáforas de posição e localização. Dois pontos importantes se destacam, na narrativa, quanto à valorização do status gerencial: (i) a distinção dos Administradores como os que não ocupam o mesmo status de outros trabalhadores, ou não pertencem ao mesmo estrato dos demais; (ii) o reconhecimento material correspondente a tal status. Especialmente no grupo de alunos, há uma ênfase na diferenciação do Administrador em relação a outros profissionais, e a tendência de apresentar o contexto organizacional por uma lógica estratificada. Esses aspectos emergiram também relacionados à expectativa de um retorno financeiro diferenciado. Mills (1979) considerava a renda um fator de distinção de status entre operários e "colarinhos-brancos", em que estes últimos estariam em uma posição de meio-termo, sendo a questão da propriedade um ponto em comum: nas burocracias modernas, ambas as categorias profissionais são nãoproprietárias.

Em contraste com o lado otimista da questão, a narrativa totalizante carrega, por vezes, o tom da desvalorização, da revolta com a concorrência na área, e mesmo a frustração pessoal pelas peculiaridades da profissão. A importância da Administração é evocada em conjunto com um clamor pelo reconhecimento social dessa importância, muito distante discursivamente do prestígio social de outrora. Nesses termos, as falas se aproximam da síndrome da sobrevivência, que ataca, principalmente, a gerência intermediária nos dias atuais, síndrome esta relacionada à falta de garantia de uma carreira promissora, segurança e estabilidade no trabalho, mesmo que em troca de lealdade (BITTENCOURT NETO, 2004).

Sobre esse aspecto da segurança pecuniária e da estabilidade, observa-se que alguns destinos profissionais dos entrevistados, quer os vividos por eles, quer os projetados para seus personagens ficcionais, guardam relação com essa busca pela segurança e perspectivas de carreira, que eles não localizam na prática gerencial tradicional, corroborando o que dizem Brocklehurst, Grey e Sturdy (2009) quanto à atual erosão dos privilégios dos gerentes burocratas em termos de segurança. Assim, os entrevistados pegavam outras "rotas" profissionais que guardassem alguma relação com a Administração, mas que lhes desse mais segurança e reconhecimento material e simbólico, como, por exemplo, a docência e a propriedade. Mesmo os que idealizaram uma trajetória ascendente como gestores empresariais, como Dan, sempre terminaram a narrativa apontando o empreendimento próprio como futuro almejado, como se o posto gerencial como empregado fosse apenas uma passagem necessária, mas não definitiva, em seus horizontes profissionais.

Os aspectos materiais, contudo, não são suficientes para explicar a desvalorização e perda de status de uma profissão. Brocklehurst, Grey e Sturdy (2009) lembram que status é um fenômeno complexo, apenas parcialmente relacionado com recompensas materiais. Nos territórios da Administração, os autores incluem tal fenômeno em um processo maior de desvalorização da área, que inclui dois aspectos: "uma proposição é que o management está em declínio como uma atividade que está se tornando rara. A outra é que o management está em declínio como uma atividade que tem status" (BROCKLEHURST, GREY e STURDY, 2009, p. 8).

A raridade da Administração como atividade específica e restrita a um grupo profissional guarda relação com o frequente discurso contemporâneo da autogestão, do empowerment, da Administração como atividade incentivada e que se tornou possível a todos. Esse aspecto emerge de modo indireto na narrativa, não nomeado pelos entrevistados como autogestão, estando, contudo, mais associado ao tema da concorrência, pelo qual muitos outros profissionais podem e fazem o trabalho do administrador, como também o discurso de que, se a Administração serve pra tudo, para gerenciar desde a vida privada às organizações, todos estariam habilitados a exercê-la. 
Assim é que a síndrome da sobrevivência de que fala Bittencourt Neto (2004) assola especialmente a gerência intermediária, que se vê reduzida dentro das empresas que tenham passado por reestruturações e assumido estruturas mais enxutas, como os entrevistados reconhecem ser a tendência atual, e também pelo movimento de incentivo a que todos dentro da organização gerenciem o próprio trabalho. Champy (1995), por exemplo, anuncia a entrada da gerência no rol das profissões perigosas e circunstancia o êxodo gerencial em três ondas: (i) a de redução de custos; (ii) a da gerência que não agrega valor; e (iii) a da TI substituindo atividades gerenciais; para, finalmente, apresentar a reengenharia como aquela que questiona a necessidade da existência de muitos gerentes nas organizações, na medida em que torna o trabalho mais autogerenciado. E mesmo Drucker (1975), defensor e propagador do boom administrativo, muda para a opinião de que a Administração como atividade restrita a Administradores deve se tornar cada vez mais inapropriada.

A raridade da Administração como atividade detentora de status é própria de um discurso como o contemporâneo, segundo Brocklehurst, Grey e Sturdy (2009), que não atribui à gerência qualquer status distintivo e ainda a acusa de ser fonte das "doenças organizacionais". É o caso, por exemplo, do discurso de Deming (1990) nos territórios da qualidade, que investe na culpabilização da Administração pelos problemas de crescimento empresarial em tempos de competitividade. A visão de lugar-comum da Administração, qualificada por participantes da pesquisa de Grey (1999) como “onipresença” da Administração e pelos entrevistados dessa pesquisa também como "onipresente" (aquela que está em tudo e é de todos, espécie de domínio público), realmente parece solapar a Administração não só como atividade, mas o Administrador como profissional com status, na medida em que, se todos podem e fazem o que ele faz, não há mais justificativa para um status diferenciado. Embora emerjam falas de que ainda é muito bonito ser chamado de Administrador, essa mesma narrativa associa frustração e angústia à profissão escolhida.

Diferentemente da visão de uma culpabilização acrítica dos Administradores, a despeito deles historicamente servirem ao capital (COVRE, 1982; FARIA, 2004a), entende-se como Brocklehurst, Grey e Sturdy (2009, p. 8) que "variações no status de uma ocupação pode ocorrer por razões que fogem ao controle de seus membros"; ou como Gaulejac (2007, p. 12) quando afirma que "sabe-se hoje que a linha reta e segura do progresso pessoal depende de variáveis que escapam do controle do sujeito". A tensão expressa nesse primeiro grupo temático guarda relação com as transformações em curso no capitalismo, cujas consequências pessoais e sociais são amplas, mesmo em espaços ocupacionais que lhe foram caros em um tempo histórico tão recente. Se as mudanças atuais não atingem a alta gestão, é forçoso admitir que os níveis gerenciais intermediários, aqueles para os quais os cursos de graduação "fornecem” anualmente um enorme contingente de força de trabalho, são atingidos de maneira expressiva, gerando situações existenciais conflituosas e desestruturantes.

O Grupo Temático II é integrado pelos temas abrangência, amplitude e utilidade, os quais emergiram, predominantemente, nas falas dos professores e alunos, tendo ecoado esparsamente na narrativa dos administradores. Os grupos de professores e alunos elaboram tais temáticas com uma alternância avaliativa, em que a amplitude da Administração tanto pode ser vista como vantagem, como diferencial gerador de oportunidades profissionais, mas também como limitação quando comparada a outras áreas com foco definido.

Quanto à avaliação negativa dessa amplitude ou abrangência de conhecimento do campo administrativo, é possível encontrar eco na literatura em pelo menos dois momentos específicos. Na abordagem clássica, identifica-se o incômodo de Fayol (1989) com tal amplitude ou indefinição da Administração, no início do século XX, problema para o qual via como solução a proposição de uma doutrina administrativa que tivesse contornos próprios. Assim foi que propôs sua lista de princípios e códigos para a matéria administrativa, esta tomada como um conjunto de funções a serem desempenhadas pelo Administrador, e este pautando-se em tais princípios doutrinários.

Atualmente, a conotação negativa da abrangência da Administração guarda certa relação com as temáticas da desvalorização e perda de status debatidos no primeiro grupo temático. Brocklehurst, Grey e Sturdy (2009), por exemplo, afirmam que o management difere de outras ocupações profissionais, mesmo de profissões com atividades mais ligadas a aspectos comerciais, como a contabilidade. Os autores afirmam que o debate 
gira em torno da dúvida se o management é essencialmente o tipo errado de conhecimento ou se é porque ele próprio tem sido incapaz de persuadir que é o tipo certo de conhecimento, mesmo que se apresente tão amplo e por vezes indefinido, razão pela qual teria que procurar por status em todo lugar, tendo frequentemente o efeito contrário da progressiva diminuição do mesmo.

Essa espécie de grande passeio que a Administração faz em diversas áreas do saber, isto é, o seu caráter multicientífico e multidisciplinar, bem como a versatilidade de ir do senso comum às teses de doutorado (RAYMUNDO, 2006), ou, ainda, a possibilidade de ser considerada ciência por uns, e arte por outros, como alerta criticamente Aktouf (2005) e, ainda mais, o paradoxo de ser considerada as duas coisas ao mesmo tempo; todo esse "passeio", enfim, acaba resultando no questionamento sobre a pertinência de se considerar uma área tão ampla e abrangente, como é a Administração, uma profissão. Essa queixa, por outro lado, foi considerada ilegítima por defensores da necessidade de administradores profissionais, à época de ascensão da gerência no Brasil, como Pereira (1966), que afirmava: "ninguém nega a existência de administradores profissionais, mas é muito comum ouvirmos a afirmação de que a Administração não é uma profissão. Torna-se difícil compreender semelhante posição. A Administração é sem dúvida uma profissão, desde que é uma atividade especializada, remunerada, com objeto próprio e constitui a fonte de receita, por excelência, daqueles que a exercem" (PEREIRA, 1966, p. 89).

Castro (1974) compartilhava da visão de Pereira (1966) sobre a emergência e necessidade dos administradores como profissionais estratégicos para consolidação do processo de industrialização nacional. Ele destacava, em meados da década de 1970, o aspecto frágil da formação em Administração em detrimento de outras áreas do saber, como a Economia, que tinha uma formação teórica geral mais sólida. Castro (1974) também comentava, à época, sobre a abrangência própria ao termo Administrador dentro das empresas, por considerar que ele podia significar tanto o técnico especializado quanto o tomador de decisão, situações ocupacionais que ele considerava pertencentes a polos extremos e com demandas de formação diferenciadas.

Por outro lado, considerar a Administração uma profissão com demandas de formação universitária abrangente não parece ser a compreensão de autores como Deming (1990). Falando desde o contexto norteamericano, Deming (1990) argumenta tratar-se de uma brincadeira cruel dizer que administrar é uma profissão e que os que passaram pelas escolas de negócios estão preparados para assumir os altos postos gerenciais das empresas daquele país, argumentando, ainda, que há um escopo de disciplinas que se constituem como formação do manager, mas outras que significam apenas um desenvolvimento de habilidades as quais ele julga mais adequado serem aprendidas e desenvolvidas na empresa. Assim, Deming (1990) reconhece a amplitude de conhecimentos próprios à área, mas acomoda em categorias diferentes formação e habilidades - e em espaços também distintos de acesso e desenvolvimento: a universidade e a empresa.

Em relação à avaliação positiva da amplitude da Administração, tanto no grupo de professores quanto no de alunos, há uma tendência a resolver o impasse que ela gera a partir do tema utilidade, que emerge em duas perspectivas: (i) a utilidade para a empresa; e (ii) a utilidade para a vida. Os alunos tendem a valorizar a abrangência de conhecimentos da Administração como útil para o contexto empresarial. Eles investem em um discurso pelo qual o estudante de Administração pode não saber para quê aquele conhecimento situado entre extremos servirá (da matemática à psicologia), mas que em algum momento de suas trajetórias profissionais, nas empresas, fará sentido. Eles defendem a característica da abrangência ou da pluralidade de conteúdos como inerente à Administração e à formação do Administrador, mesmo que a validade dessa abrangência só se verifique a posteriori, como uma espécie de aposta no futuro.

As professoras argumentam sobre sua utilidade mais ao nível pessoal, como que dizendo: se tudo o que se estuda em Administração não servir para a vida profissional, ao menos servirá para a vida pessoal. Como mencionado anteriormente, toda a incerteza que envolveu a vida das professoras quando da escolha de curso, foi racionalizado em termos da utilidade que esse campo de conhecimento amplo e abrangente poderia trazer para suas vidas. 
Voltando a Taylor (1986), por exemplo, vê-se que esse tipo de pensamento de utilidade da Administração, para tudo na vida e na sociedade, não é uma novidade. É algo que já vem sendo incutido como ideologia gerencialista que transpõe os territórios da fábrica desde a passagem do capitalismo familiar para o capitalismo burocrático. Taylor (1986) defendia a universalidade dos princípios da Administração, o que significava, para ele, a aplicação desses princípios às mais diversas esferas da vida humana associada: lares, fazendas, casas comerciais, igrejas, universidades, governos etc.

A lógica dessa ampla área que é a Administração servir para tudo não é uma mera questão retórica e não é considerada simples por autores como Grey (1999) e Gaulejac (2007), os quais entendem tal compreensão como associada a uma visão gerencialista da vida e do mundo como um todo. Para Grey (1999), por exemplo, a ascendência da perspectiva de que o management serve para tudo e é de todos é correlata ao seu declínio ou desvalorização como profissão, na contemporaneidade, com correspondente rompimento dos limites organizacionais para a prática do mesmo. Uma consequência possível, julga o autor, é que se estaria ampliando a racionalidade instrumental própria ao management para todas as dimensões da vida humana associada, fenômeno que, Gaulejac (2007, p. 28) elabora em termos de maior abrangência e, portanto, maior alcance da ideologia gerencialista: nascida na esfera do privado, a ideologia gerencialista tende a se espalhar nos setores públicos e no mundo não comercial. Hoje, tudo se gere - as cidades, as administrações, as instituições, mas também a família, as relações amorosas, a sexualidade, até os sentimentos e emoções. Todos os registros da vida social são atingidos. Cada indivíduo é convidado a se tornar o empreendedor de sua própria vida. Essa compreensão, de fato, encontra eco e até mesmo legitimação na narrativa dos sujeitos ouvidos nessa pesquisa.

O Grupo Temático III é composto por um mix de temas intrinsecamente relacionados que atravessam a narrativa na sua totalidade, com facetas próprias em cada grupo de sujeitos. De um lado, há a recorrência de falas ligadas a temas operacionais como ação, atividades, fazeres, sendo estes relacionados a conhecimentos aplicados/tecnologia; e, por outro lado, temas relacionados à formação e conhecimentos que habilitariam o Administrador a tal operacionalização, como, por exemplo: saberes, aprendizagens, experiência.

No grupo de professoras, há a recorrência dos temas saberes e fazeres, experiência e conhecimento aplicado. Tais temas fazem emergir a lógica pela qual as docentes concebem o saber e fazer administrativo, a partir da qual tendem, por um lado, a pluralizar os tipos de conhecimentos necessários ao Administrador para conduzir-se bem na profissão (saber técnico, saber interpessoal, saber organizacional), bem como pluralizam as fontes desses conhecimentos: está na teoria e na experiência, na escola e na empresa. Por outro lado, elas condicionam a validade desses múltiplos conhecimentos, acessados em várias instâncias, pelo critério da aplicabilidade: ele vale se for aplicável, utilizável. Uma síntese do pensamento das professoras é que elas estruturam o currículo de Administração e de formação do Administrador em saberes técnico, interpessoal e organizacional, localizam sua origem e destino na dimensão da experiência e condicionam sua validade pelo critério da aplicabilidade, como uma espécie de saber tecnológico.

Os alunos, por sua vez, são contundentes ao enquadrar discursivamente os dois construtos - Administração e Administrador - em um contexto de práticas, de experiência, de vivência, de fazeres, aqui nomeado ação. Há falas que rechaçam a possibilidade da não concretização dessa ação, ou de uma correspondente permanência no campo da abstração, o que eles veem como característica de várias disciplinas do curso. Tal ação é para eles a garantidora de sentido do curso e da profissão que escolheram. Localizam no contexto da ação a necessidade de aplicação, de utilização de ferramentas, entendendo a Administração tanto como meio, isto é, como algo a ser aplicado nesses contextos demandantes, mas também como ela própria precisando lançar mão sistemicamente de outros meios - ferramentas - para cumprir os objetivos desse contexto. Assim, a Administração emerge como um conhecimento aplicado ou como mediadora de outros instrumentos de aplicação, e portanto, como uma tecnologia. Uma síntese possível de como os alunos pensam esses temas é que eles concebem a Administração como uma ação tecnológica plural, pela qual as dimensões das suas experiências e vivências, atuais e futuras, constituem-se como instância de formação complementar à universidade, sendo essa ação cativa ao contexto organizacional. 
Quanto a esse grupo temático, os administradores foram os que mais citaram conteúdo corrente na literatura da área para descrever a Administração e o trabalho do Administrador. Eles reproduzem discursivamente a literatura clássica que apresenta a Administração e o trabalho do Administrador como o desempenhar de atividades sistemáticas, como planejar, organizar, coordenar, controlar, tendo em vista a finalidade sistêmica de fazer a organização funcionar. Sobre as aprendizagens, eles as trazem na mesma perspectiva plural com que as professoras falam dos saberes e fazeres. São diversas as aprendizagens e as mesmas se dão em diversos lugares, mas, principalmente. na universidade e nas organizações de trabalho. As metáforas predominantes foram a da reciclagem, por meio da qual defendem a necessidade do aprender de novo, e de sempre ser necessário reiniciar o processo de aprendizagem; e a da abertura de mente e coração, pela qual caberia à universidade o papel de fazer essa abertura, visando preparar o futuro Administrador para as aprendizagens que ocorreriam nas organizações. Sobre a necessidade de reaprender sempre, eles justificam pelos diferentes focos das diversas organizações de trabalho por que venham a passar durante o exercício profissional. A cada nova experiência de trabalho, novas aprendizagens devem se efetivar.

Uma proposição sintética do pensamento dos administradores no que se refere a esse grupo temático é que, mesmo há algum tempo longe da universidade, eles tendem a reproduzir acriticamente a concepção teórica clássica da Administração como um processo sistemático de planejamento, organização, coordenação e controle, e a acomodar tal visão em um pensamento sistêmico funcionalista. Por outro lado, trazem um conteúdo corrente na atualidade que é o da aprendizagem, apresentando a universidade como a que prepara o graduando para aprender continuamente depois, nas organizações de trabalho, sendo as experiências que se desenrolam nesse ambiente as qualificadoras de tal aprendizagem.

Na narrativa totalizante, os temas operacionais tendem a reproduzir, como corrobora Grey $(1999$, p. 569), um "certo tipo de conhecimento [de que] management é o que os gestores fazem"; e, ainda, que "o administrador é definido como um homem, ou uma mulher, de ação" (AKTOUF, 2005, p. 154). Falas que focam a gerência como ação, como prática, encontram amparo nas mais diversas proposições teóricas ao longo do século XX. De Fayol (1989) a Ohno (1997), passando por Drucker (1975) e Mintzberg (2009), encontra-se a defesa desse tipo de concepção. Leituras clássicas que influenciaram a formação do pensamento administrativo ocidental, como bem tipifica Fayol (1989) com sua prescrição das funções plurais de prever, organizar, coordenar, comandar e controlar, ainda são frequentemente evocadas e reproduzidas. A esse respeito, no contexto brasileiro de ascensão da gerência, pelo idos da década de 1960, Pereira (1966) criticava a opinião corrente de que a Administração não era uma profissão, recorrendo exatamente à descrição das funções fayolistas para qualificar o objeto da Administração e o trabalho do Administrador:

um administrador de empresas profissional é aquele indivíduo que, sem possuir a propriedade de uma empresa, toma decisões com autoridade sobre seus recursos humanos e materiais, planejando, organizando e controlando suas operações. É o homem que realiza essas funções especializadas em razão de sua competência profissional, e não por ser o proprietário da empresa ou por manter com estas relações de parentesco ou amizade (PEREIRA, 1966, p. 89).

Tanto autores brasileiros, como Pereira (1966), quanto autores que escreviam desde o contexto anglo-saxão sobre a emergência da gerência (MILLS, 1979; CHANDLER (1962; 1984), eram unânimes em acomodar o uso dessas funções, pelo Administrador profissional, em uma localização específica: a organização moderna burocratizada. Para Mills (1979, p. 89):

a ascensão de milhares de pequenas e grandes burocracias e a minuciosa especialização do sistema em geral criam a necessidade de que muitas pessoas planifiquem, coordenem e administrem as novas rotinas desempenhadas por outros. $\mathrm{O}$ desenvolvimento de unidades de atividade econômica cada vez maiores e mais complexas aumenta a proporção de empregados dedicados a tarefas de coordenação e gerência. Há necessidade de dirigentes, técnicos e empregados de escritório de todos os tipos - supervisores de seção, contramestres, chefes de escritório; pessoas às quais os seus subordinados prestam contas e 
que, por sua vez, devem prestar contas a seus supervisores, elos das cadeias de poder e obediência, coordenando e supervisionando as experiências, funções e capacidades de outros.

Em diversos trechos da narrativa, é esse o cenário valorizado pelos entrevistados, especialmente quando reclamam um status privilegiado dentro de um contexto estratificado; quando almejam um contexto profissional em que são considerados importantes para solução de problemas pelo desempenho dessas funções, mesmo que não se acomodem discursivamente nessa condição por toda a vida profissional. Esse tipo de atividade, de ação gerencial própria à organização burocratizada foi qualificada por Weber (1994) como uma ação racional referente a fins, com uma correspondente ética da responsabilidade. Assim, o Administrador figura como aquele que exerce sua profissão primordialmente orientado em relação às finalidades e regido por uma ética da responsabilidade (RAMOS, 1983). Uma prática direcionada a finalidades também foi o ponto fulcral para autores neoclássicos como Drucker (1975), que, em lugar de ciência, concebia a Administração como uma prática necessariamente comprometida com o desempenho empresarial.

Essa ação gerencial, então, seria sempre regida pelas finalidades, a despeito dos meios, como racionalizado pela aluna Mari em relação à forma como ela concebia e gerenciava as pessoas com o intuito de levá-las a se identificar com a organização: uma gerência estratégica, que não necessariamente toma as pessoas como pessoas, mas que as coloca como meios para alcance dos objetivos organizacionais, configurando a concepção da Administração como um fazer-fazer (ALBANDES-MOREIRA, 2002). Tais concepções exemplificam a extensão da supervisão gerencial citada por Mills (1979): supervisão das funções, das capacidades, mas também das experiências dos outros, por parte do Administrador.

A frequente recorrência na literatura em relação à existência de variados tipos de recursos gerenciáveis nas organizações, principalmente materiais, humanos e financeiros, encontra eco nesse grupo temático por meio da unidade de sentido fazer, que emerge sempre no plural. Para os entrevistados, nos territórios da Administração, trata-se sempre de fazeres múltiplos, associados a saberes também diversos, que eles apresentam como de três tipos: técnicos, gerenciais e organizacionais.

Pelo menos parcialmente, tal classificação faz lembrar o pensamento de Fayol (1989) que distinguia dois tipos de capacidades que julgava necessárias às empresas: a técnica e a administrativa, sendo esta última própria do Administrador e mais ligada a aspectos comportamentais. Ambas as capacidades, para Fayol (1989), careciam de formação combinada ou complementar entre escola e empresa. Semelhante diferenciação foi a proposta por Drucker (1975) entre o profissional de carreira, aquele que detém um conhecimento especializado e supervalorizado pela organização, e o Administrador, o responsável pela transmissão de conhecimento e tomada de decisão. A pluralidade de fazeres e saberes da Administração também é referida por autores brasileiros como Castro (1974) em sua divisão dos gerentes entre o técnico especializado e o tomador de decisão, ou a classificação de Silva (2009) em: (i) conhecimento técnico; (ii) habilidades gerenciais; e (iii) compreensão da organização, do impacto nos outros e de si mesmo.

O trânsito entre as áreas técnicas e gerenciais parece, inclusive, ser um ponto de tensão para o Administrador em comparação com outras profissões, especialmente as que têm um lado técnico mais destacado, como a engenharia, que parece dar força aos temas da desvalorização e concorrência que integram o primeiro grupo temático. A esse respeito, Bittencourt Neto $(2004$, p. 8 ), ao falar do mal estar que assola a gerência intermediária na contemporaneidade, circunstancia a questão nos seguintes termos: "as gerências intermediária e operacional apresentam o desconforto causado em vencer a resistência particular oriunda da imposição de abandonar a carreira técnica em prol das funções gerenciais por parte da empresa, em consequência do crescimento do negócio. Os profissionais que assumiram alguns cargos de gerência são engenheiros com reconhecida experiência técnica".

Assim é que se percebe na narrativa, em particular no discurso do aluno Dan, a insistência em unir ou mesclar dois tipos de saberes para a prática profissional futura (técnico na área de Tecnologia da Informação 
e superior em Administração), como que garantindo, ainda no período de formação, a possibilidade de ter posto de trabalho nos dois tipos de fazeres - técnico e gerencial -, tornando-se, então, imprescindível. Uma inferência possível é que a pluralidade de fazeres de que falam e que a literatura sustenta favorece mais a profissionais com outras formações, em áreas com um foco técnico mais definido, do que Administradores, para quem resta fazeres mais performáticos do que conteudísticos, ou saberes e fazeres extremamente dependentes de um contexto organizacional específico, com consequências que não devem ter sua importância minimizadas, como, por exemplo: (i) impossibilidade de formação prévia adequada; e (ii) novas (con)formações a cada experiência de trabalho. Sobre esta última, Sennett (2007), em sua leitura reflexiva sobre esses tempos de flexibilidade, alerta quanto ao risco de corrosão do caráter, pela impossibilidade de desenvolvimento de relações duradouras, aquelas que eram próprias às carreiras burocráticas.

Ao evocarem essa pluralidade de saberes e fazeres do Administrador, os entrevistados convergem para a compreensão da Administração como saber e fazer tecnológico, em que o tipo de conhecimento valorizado na área é sempre um conhecimento aplicado. Faria $(2004 a, 2004 b)$ adverte sobre o cuidado de não se restringir o conceito de tecnologia ao uso de máquinas no processo produtivo. Ao entender tecnologia como o conjunto de conhecimentos aplicados a uma atividade (FARIA, 1992; 2004a), o autor apresenta as tecnologias de gestão como um tipo específico de tecnologia, na medida em que se constituem como instrumentos ou estratégias de gestão da força de trabalho. Faria (1992; 2004a) as classifica, então, em tecnologias de gestão de ordem instrumental e tecnologias de gestão de ordem comportamental e ideológica, em que as primeiras, em geral, relacionam-se às técnicas e estratégias de racionalização do trabalho, e as segundas a qualquer ação gerencial de manipulação e modelização do comportamento.

Na narrativa, identifica-se nos grupos de professores e de alunos a tendência a fazer uma certa categorização dos saberes e fazeres que se mostram exemplares da compreensão de Faria (2004a). No grupo de alunos, vemos a tendência à valorização das tecnologias de gestão de ordem comportamental, tal como a gestão estratégica de pessoas proposta por Mari. O grupo de professoras, ao classificar os saberes e fazeres da gerência em técnicos, interpessoais e organizacionais, credita ao primeiro a possibilidade de solução de problemas no trabalho diário, tal como fazem os engenheiros; destacam, também, especialmente, a importância do segundo para o administrador, um tipo de saber que diz respeito, para elas, à capacidade de lidar com pessoas, conhecendo-as, motivando-as, e até mesmo corrigindo-as; e o terceiro tipo ligado à possibilidade do gestor ser o portador de uma "memória organizacional".

Esses temas operatórios são sustentados, na narrativa, pelo segundo grupo de temas que lhe conferem um sentido interessante: as aprendizagens e as experiências. Para se voltar à ação, aos fazeres, às práticas, o Administrador necessita passar por processos de aprendizagens diversificados e por experiências.

O grupo que mais colocou a questão das aprendizagens foi o de administradores, os quais falaram principalmente a partir de suas histórias de vida estudantil e profissional. Eles insistiram no fato de que havia muita aprendizagem além dos muros da universidade. Essa ideia, de fato, não é nova, ou é de "berço" nos territórios da Administração, quando se relembra Fayol (1989) afirmando que a capacidade administrativa deveria ser adquirida em duas instâncias: a escola e a oficina. Ao tratar a Administração em termos de doutrina administrativa, Fayol (1989) apresenta como papel da escola o de inculcar esse tipo de conhecimento nos futuros Administradores.

Desde autores clássicos como Fayol (1989), percebe-se que a formação ou os tipos de aprendizagens tidos como necessários ao Administrador transcendem os aspectos meramente técnicos de um ofício. $\mathrm{O}$ Administrador, de antemão, precisa se preparar para ser de uma determinada maneira no contexto de trabalho. Assim é que, na contemporaneidade, temáticas como a das emoções são trazidas para o debate sobre a aprendizagem de gerentes (SILVA, 2009), como que corroborando a "mente e coração abertos" colocada pelos entrevistados como sendo a parte que caberia à universidade nas aprendizagens necessárias ao Administrador. Como corroboram Brocklehurst, Grey e Sturdy (2009, p. 9-10), na atualidade, "os atos educacionais nos territórios do management representam mais um filtro ou mecanismo de socialização do que um veículo para transmissão de conhecimento utilizável”. 
Silva (2009) organiza essa multiplicidade de aprendizagens em termos de educação gerencial (sistema educacional) e desenvolvimento gerencial (mecanismos de mercado), e entende essas duas dimensões ao mesmo tempo como distintas e sobrepostas, mas tende a valorizar a segunda para formação dos Administradores quando afirma:

a discussão em torno da relação entre educação e aprendizagem nos programas que fomentam a aprendizagem de gerentes nas organizações deve considerar que a educação não leva necessariamente à aprendizagem e que esta não está necessariamente conectada com a educação. Para que a aprendizagem ocorra, torna-se necessário que haja uma troca entre o indivíduo e a situação de trabalho. [...] O gerente deve encarar a aprendizagem como dinâmica e contextualizada ao ambiente da sua prática (SILVA, 2009, p. 154-6).

É nesse sentido, o de enquadrar a aprendizagem dos gerentes especialmente no contexto das práticas, que tanto os entrevistados quanto literaturas clássicas e contemporâneas do campo, evocam o último tema desse grupo: a experiência. Fayol (1989) falava que saber avaliar era uma das principais qualidades do Administrador e a mesma era resultado do tato e da experiência. Para Silva (2009, p. 179): "as palavras 'experiência' e 'aprendizagem' estão intimamente relacionadas. [...] No ambiente empresarial, a palavra 'experiência' está associada a um conhecimento prático de como atuar em determinada situação profissional. A experiência faz parte do saber prático do gerente na ação".

A recorrência do tema experiência, em todos os grupos, leva a pensar sobre qual tipo de experiência os entrevistados estão falando. Um exame minucioso indica serem várias as perspectivas pelas quais eles abordam a questão. Há a predominância de três tipos de perspectivas: (i) experiência associada a uma localização sistêmica do Administrador, como ocupante de função na organização-sistema; (ii) coisificação da experiência, ao tratá-la como algo que se carrega, que se ganha, que se adquire, que se tem; e (iii) experiência como instância de formação do administrador.

Pela primeira perspectiva, a experiência do Administrador não se dá a partir da ação individual espontânea ou como fruto de relações interpessoais informais próprias ao convívio social no contexto do trabalho; a experiência emerge a partir dos critérios formais de inclusão do profissional da Administração como um trabalhador que desempenha funções dentro de uma organização pensada sistemicamente. Com essa inscrição, pode-se compreender que eles falam sobre a experiência de alguém colocado (e se colocando) na condição de elemento sistêmico, o que dá contornos próprios a tal experiência.

Semelhantemente, Silva (2009) argumenta que a experiência é de importância determinante para a aprendizagem gerencial por possibilitar ao gerente, através de um raciocínio sistêmico, ter uma compreensão mais rica e ampla do seu papel. A lógica sistêmica também emerge como fundamento em outras perspectivas que relacionam as experiências e a aprendizagem no contexto do trabalho, como em Senge (1990), ao propor quatro disciplinas - domínio pessoal, modelos mentais, visão compartilhada, aprendizado em grupo fundamentadas no pensamento sistêmico. Por esse tipo de pensamento, que liga tudo e todos na organização por uma lógica sistêmica, é que autores como Senge (1990) fazem a extrapolação da experiência individual para o paradoxo de uma aprendizagem não mais individual, mas organizacional, pela qual os resíduos de individualidade das experiências e aprendizagens se diluem na organização-sistema, pela antropomorfização velada das organizações no discurso da aprendizagem organizacional.

É, então, de maneira alinhada à perspectiva sistêmica que emerge a segunda representação: a da coisificação da experiência, para a qual também, sem dificuldades, encontra-se respaldo frequente na literatura que versa sobre a aprendizagem gerencial: "a experiência tanto pode ser adquirida mediante um processo de aprendizado sistemático, aprimorado no decorrer do tempo, como também é um conhecimento obtido de forma mais abrangente e não estruturada, adquirido ao longo da vida, por meio das relações sociais" (SILVA, 2009, p. 179). Assim, novamente, a experiência, em lugar de ser narrada como um processo individual e social espontâneo, próprio à vida humana corriqueira, ela é tipificada pelos sujeitos e pela literatura da área, como uma coisa a ser adquirida, transacionada, possuída, barganhada, tal qual um produto 
com valor, que, se usado pelo Administrador sob uma lógica instrumental - tal como quer Max (administrador entrevistado): enriquecer-se de experiências pegando os "tiquinhos de cada um", por onde passar, terá seu valor aumentado.

Assim, a terceira concepção de experiência dos entrevistados emerge como uma consequência das duas primeiras: a experiência sistêmica circunstanciada no "mundo das práticas", adicionada de valor ao longo da caminhada, transforma-se na instância ideal de formação do Administrador, com um valor potencializado quando comparada à experiência de formação universitária tradicional, que, para eles, parece deslocada do mundo real. Esse tipo de experiência lhes parece mais interessante pela perspectiva instrumental com que lidam com a mesma: ela é uma experiência enriquecedora porque os habilita para algo, porque serve para o próprio contexto imediato em que se dá, em uma espécie de movimentos circulares permanentes. Ela não tem valor substantivo em si mesma, ela é uma experiência rica e que forma o gerente porque serve à organização em que ele está na condição de elemento sistêmico. Vale lembrar que tal perspectiva sistêmica instrumentalizante da "experiência" não é nova para a Administração, como já prescrevera Fayol (1989, p. 43), ao ensinar sobre como surgem os princípios em matéria administrativa: "qualquer regra, qualquer instrumento administrativo que fortaleça o corpo social ou facilite seu funcionamento pode-se alinhar entre os princípios e durante o tempo em que a experiência o confirmar nessa posição". Logo, desde Fayol (1989) falava-se de experiência, menos em sentido de uma vivência individual, e mais na perspectiva de práticas funcionais no interior de uma organização tomada como um sistema orgânico, naturalizada.

O Grupo Temático IV é formado pelos temas visual, estilo e perfil, apresentando-se como o grupo temático mais diretamente relacionado ao construto Administrador e, por isso, o mais personalístico de todos. Os temas que o compõem emergem nos grupos de alunos e administradores. No primeiro, recorrem os temas visual e estilo; os administradores, por sua vez, apresentam o tema perfil como qualificador do Administrador.

Por esse grupo temático, os entrevistados indicam que a possibilidade de ser (ou estar) Administrador achase menos relacionada à capacitação ou formação para tal, mesmo que dela não se possa prescindir, do que a dimensões ligadas à performance, tanto em termos das práticas/ações/experiências discutidas no terceiro grupo temático, mas aqui principalmente por aquilo que pode ser mostrado e visto, a partir de um estilo próprio ou aprendido por esse Administrador. Essas seriam as garantias para adquirir e situar-se em um status privilegiado, o do administrador-líder, figura situada sempre à frente, ou acima, no espaço organizacional.

Esse grupo temático intercambia com o primeiro grupo no que toca à dimensão status, donde uma síntese possível é: ao considerarem o status como definidor de quem é o Administrador no contexto organizacional, os entrevistados entendem que o alcance de tal posição lhes exige: (i) o atendimento a um perfil específico, que pode ser aprendido em situações de formação ou ser nato, perfil que também deve servir de modelo para outros; (ii) a capacidade de ver e aprender um estilo próprio e compatível com o status pretendido; e (iii) a capacidade de mostrar-se detentor desse perfil e atuante nesse estilo; assim, associam a profissão mais a dimensões performáticas do que a aspectos conteudísticos.

Novamente, também, os temas desse grupo encontram eco em autores clássicos, como Fayol (1989, p. 37), que dava contornos próprios ao tema:

Se se trata de escolher um contramestre entre os operários, um chefe de oficina entre os contramestres ou um diretor entre os engenheiros, não é nunca a capacidade técnica que decide a escolha. Verifica-se se o escolhido possui a dose necessária de capacidade técnica, mas, entre os candidatos de valor técnico quase equivalente, será dada preferência ao que for considerado superior por suas qualidades de presença, autoridade, ordem, organização e outras que são os próprios elementos da capacidade administrativa. 
Uma identificação importante no pensamento de Fayol (1989) é que ele apresentava o Administrador como um modelo ou como um exemplo a ser seguido, logo, muito mais relacionado a um "saber ser", a um comportar-se de determinada maneira, do que a um "saber fazer" um trabalho, desde o ponto de vista técnico de um ofício. Também em autores da época de ascensão da gerência brasileira pode-se identificar essa distinção entre um trabalho técnico e um trabalho ligado a características individuais. Castro (1974, p. 61), ao propor as tipologias de administradores técnicos e administradores tomadores de decisão, esclarece: "nas funções de decision-making, atributos pessoais são mais relevantes para a performance do que propriamente a formação universitária, [assim], podemos recrutar livremente para estas funções engenheiros, advogados, economistas e técnicos de administração".

Esse tipo de concepção sobre o trabalho do Administrador favorece, inclusive, a situação de concorrência com profissionais de outras áreas, como abordado no primeiro grupo temático, uma vez que, como Castro (1974) defende, atributos individuais prescindem da formação acadêmica, podendo, portanto, ser encontrados em profissionais de outras áreas. Assim, o Administrador como trabalhador performático, com perfil e estilos adequados ao status pretendido, sofre a concorrência direta de profissionais de outras áreas. Será por isso que os entrevistados insistem na metáfora ótica ou da visibilidade, pela qual precisam ser permanentemente vistos em suas performances para garantir o posto de gerência?

Em épocas mais recentes, e com contornos próprios, autores como Champy (1995), em suas proposições sobre a reengenharia, também tende a apresentar os novos administradores a partir de aspectos performáticos e mesmo revolucionários, como a figura do herói, aquele que sai como vencedor nos processos de mudança empresarial servindo de modelo para todos na organização. Como o autor afirma, os gerentes mostram os novos caminhos a todos na organização, sendo "modelo de comportamento, possibilitando e educando" (CHAMPY, 1995, p. 35), à medida em que demonstra visivelmente uma forma de ser e portar-se. Também no seu conceito de autoridade existencial, para contrapor-se à autoridade formal tradicional, Champy (1995) enseja uma concepção da gestão pela qual é através do exemplo e dos resultados visíveis que os novos gestores estariam garantindo seu espaço.

Finalmente, o Grupo Temático $\mathbf{V}$ é composto por temas que, juntos, trazem um sentido convergente a uma dimensão muito significativa para os territórios da Administração, aquela que diz respeito ao lócus ou ao espaço social privilegiado para sua emergência: a organização. Os temas "mudanças", "necessidades" e "finalidades" perpassam praticamente toda a narrativa, lançando luz e privilegiando principalmente um tipo de organização: a empresa. A empresa emerge como o contexto privilegiado da gestão, à semelhança do status de instituição social atribuído por Drucker (1975). Quando falam da empresa, os entrevistados a narram como uma espécie de primeira e última razão da Administração e do Administrador. Trata-se da organização, o continente do qual Administração e Administrador lhe são conteúdos peculiares. Que necessidades? As da organização. O que deve mudar? A organização. Em nome de que finalidades? As da organização. É sempre esse o cenário no qual os entrevistados situam essas questões e a eles próprios enquanto administradores.

O tema mudança não é novo nos territórios da Administração. Embora seja frequentemente narrado como uma espécie de mantra contemporâneo, como se mudança fosse a novidade corrente da gestão em contraposição a um passado tomado discursivamente como estático no campo administrativo, ao contrário, desde Taylor (1986), e reaparecendo em Drucker (1975) e em tantos outros autores do mainstream, as mudanças são apresentadas como "tema da hora" nos territórios da empresa e sua Administração. Era sobre mudança que Taylor (1986) falava e buscava implantar com sua proposta de Administração Científica, em substituição à Administração por iniciativa e incentivo. Suas propostas eram respostas às mudanças demandadas pelo sistema capitalista de produção de então, e Taylor (1986) considerava ser necessária à figura do dirigente, enquanto promotor das mudanças, grande experiência pessoal antecedente, como uma espécie de formação pela prática, a qual the habilitaria a implantar as mudanças necessárias ao sistema administrativo. Semelhantemente, Drucker (1975) apregoava a necessidade de mudança e reestruturação na empresa e sua Administração. Ohno (1997), por sua vez, apresentava o sistema Toyota de produção como a mudança necessária para os tempos de crise e necessidades de reconstrução da indústria e economia japonesa. O que talvez marque uma diferenciação no discurso, é que, diferentemente de Taylor (1986), 
Drucker (1975) associava mudança à incerteza e descontinuidade nos territórios da gestão, como que demarcando uma requalificação do próprio sentido de mudança nesse campo.

Esse quinto grupo temático guarda estreita relação com o terceiro, pois, enquanto o terceiro apresenta a defesa dos entrevistados quanto à demanda de saberes e fazeres plurais, que se inscrevem especialmente na prática, requerendo, em uma lógica de causa e efeito, um tipo específico de conhecimento (o aplicado, o tecnológico), esse quinto grupo temático explica os porquês ou os motivos disso: é porque existem necessidades imperiosas a serem supridas, em especial, as relacionadas a mudanças e transformações, tornadas cada vez mais urgentes na atualidade, uma vez que existem finalidades a impor e determinar toda essa cadeia causal, sendo essas finalidades a de um espaço, de um lócus específico, plenamente identificado em suas narrativas: o contexto organizacional. Em geral, é a grande empresa que habita o imaginário dos entrevistados. Uma síntese possível é que os sujeitos conferem ao contexto organizacional uma espécie de poder soberano, por ser o território das necessidades e finalidades, cuja complexidade envolve uma demanda constante de transformações, impondo à Administração e ao Administrador um estado de submissão permanente.

Essa espécie de soberania conferida pelos entrevistados à organização empresarial é própria de um discurso de elevação da empresa a uma categoria de distinção na sociedade moderna, como proposto por apologistas da cultura de empresa: "a empresa é hoje, de longe, a instituição mais influente na sociedade moderna. Apenas o Estado pode a ela ser comparado em termos de poder" (RICHERS, 2005, p. 9); tipo de pensamento que permite a leitura crítica dos opositores do capital que enquadram esse tipo de representação como o discurso da empresa soberana em tempos de democracia totalitária (BERNARDO, 2004).

Para falar da empresa elevada a tal status institucional ou de soberania totalitária, a narrativa incorre em dimensões naturalizantes do construto histórico empresa, ao apresentá-la, metaforicamente, como um sistema biológico vivo que muda e que tem necessidades a serem atendidas. Novamente, trata-se de um tema recorrente no campo administrativo desde autores clássicos como Fayol (1989), ou neoclássicos como Drucker (1975), que apresentavam a empresa capitalista como um organismo vivo, utilizando com frequência metáforas como as da empresa com vida próspera, empresas que enfraquecem, empresas com órgãos de visão, empresas que andam depressa e empresas como corpo social (FAYOL, 1989), ou empresas como esqueletos, corpo, organismo e como órgãos da sociedade, esta também tomada sistemicamente (DRUCKER, 1975).

Ao evocarem temas como necessidades e mudanças, é essa mesma equiparação com organismos vivos que os entrevistados estão a fazer, mesmo que disso não se deem conta, como corrobora Morgan (1996), ao tratar das imagens metafóricas pelas quais as organizações têm sido lidas e discursadas desde a abordagem clássica até à dita flexível: as organizações são concebidas como sistemas vivos, que existem em um ambiente mais amplo do qual dependem em termos da satisfação das suas várias necessidades.

Pela lógica sistêmica, que apresenta as organizações como organismos com necessidades e que continuamente mudam e evoluem, a Administração emerge como um meio adequado para fazer tal sistema orgânico funcionar. Entretanto, o funcionamento por ele mesmo não é o fim último das organizações tomadas como organismos, são as suas finalidades ou objetivos que qualificam que necessidades atender, que mudanças realizar. Por esse raciocínio, Administração e Administrador figuram sistemicamente também como meios, como instrumentos para alcance das finalidades da organização.

Retomando Drucker (1975), percebe-se o tom quase axiomático com que eleva as finalidades organizacionais a um status de definição da própria natureza da Administração: "Administração é muito mais uma prática do que uma ciência. Não é conhecimento, mas sim desempenho" (DRUCKER, 1975, p. 20). 


\section{Síntese crítica da narrativa totalizante}

Das análises empreendidas, um primeiro movimento de síntese dessa pesquisa é que as representações dos sujeitos entrevistados integram duas concepções sobre a Administração e o Administrador, na contemporaneidade, concepções ao mesmo tempo independentes, mas que se explicam mutuamente: (i) a concepção pragmática-instrumental; e (ii) a concepção estética. A concepção pragmática-instrumental perpassa especialmente os grupos temáticos II, III e V, clarificando o que os entrevistados pensam sobre a Administração, enquanto a concepção estética se desvela especialmente no grupo temático IV e em temas do grupo temático I, expressando predominantemente suas compreensões sobre o Administrador.

A concepção pragmática-instrumental encaminha para a conclusão de que os sujeitos entrevistados definem a Administração, em sentido lato, como uma ação ampla e útil para tudo e todos. Em sentido estrito, por essa concepção, eles entendem e apresentam discursivamente a Administração como uma ação tecnológica e teleológica, que utiliza saberes múltiplos e aprendizagens cambiantes como meios para alcance das finalidades do contexto organizacional mutante. A representação que emerge de suas ideias é a do movimento. A Administração é esse movimentar-se para algo, ou em função de algo.

Pela concepção estética, eles tendem a apresentar o Administrador como um profissional performático, quando dentro das organizações. Tal concepção estética emerge com duas facetas. Em temas do grupo temático I, como status, o "belo" emerge associado à ideia de que o Administrador é aquele com posição e localização de destaque nas organizações, com merecida importância e reconhecimento, donde o lugar, o estar nesta e não noutra posição, seria o grande qualificador da sua profissão. A outra faceta estética é predominante no grupo temático IV e infere-se que ela é acionada quando há ausência da primeira, isto é, se não houver garantia do lugar, da posição, o Administrador deve "correr atrás" com um visual, estilo e perfil adequados, valorizando a dimensão da aparência como garantidora da permanência.

Uma particularidade identificada nesses resultados se refere ao Administrador. Em geral, as representações predominantes do Administrador são as ligadas ao poder e controle, ou à figura da vigilância e punição, como aquele que "faz fazer" dentro das organizações, a espécie de "mão" mediadora do capitalista, como comparava Braverman (1987). Diferentemente, os resultados desse estudo tendem a apresentar silêncio e performance como os principais qualificadores do construto Administrador, em substituição ou alternativa à concepção do Administrador como controlador e vigilante. Embora na narrativa totalizante haja esparsas emergências do tema "controle" associado à figura do Administrador, o que predominou foi a fuga da profissão; há um vazio discursivo quase unânime sobre esse profissional. Tal como nos estudos de Grey (1999), o Administrador simplesmente não emerge nas narrativas; nessa pesquisa, ele aparece apenas temporariamente, isto é, em um período da carreira dos sujeitos, para depois migrarem para outras ocupações profissionais.

Ao relacionar a concepção de Administração (pragmática-instrumental) e a concepção de Administrador (estética), um questionamento surge: se, nas concepções de Administração vem sempre se repetindo a dimensão operacional da mesma, o fazer, a prática, o resultado, a lógica finalista, por que, nas concepções de Administrador, há uma migração da lógica do "fazer fazer" para o silêncio ou para a performance? Seria mais compreensível pensar que, se a Administração é entendida pelos sujeitos como pertencente ao mundo das práticas, como um ofício meramente operatório e instrumental, posto que dirigido e destinado a finalidades específicas, caberia ao Administrador permanecer no papel de mediador e garantidor da execução por parte dos subordinados, para alcance das finalidades. Mas não é isso que eles identificam na realidade que os cerca, ou que projetam para suas vidas. Quando dizem algo, isto é, quando ainda narram sobre o Administrador dentro de um contexto organizacional como um profissional da gerência, pouco o apresentam como o mediador que "faz fazer" atrelado à autoridade conferida pelo cargo; em lugar disso, ora predomina a referência a alguém que se mostra, que se faz perceber como necessário a partir de estilo e perfil pessoal próprios, ora emerge através do amálgama entre o chefe hierárquico e o gestor-líder. 
Percebe-se que o capitalismo flexível traz em seu bojo caminhos de respostas para tal questionamento. Uma compreensão possível é que, em tempos nos quais o novo discurso ideológico gerencialista é o da generalização ou amplificação da mentalidade administrativa para toda a sociedade, seja com o conceito de autogestão, no âmbito das organizações, ou com a disseminação da lógica do gerenciamento de todas as esferas da vida por todos, além muros organizacionais, tem-se como contradição a desvalorização da área enquanto profissão restrita a poucos especialistas, no mesmo movimento de supervalorização da área enquanto conhecimento disseminado e acessível a todos ou qualquer um. A Administração, ao mesmo tempo em que é valorizada como conhecimento importante para tudo e todos, também tende a se desvalorizar como profissão restrita a um universo de profissionais com status elevado, como o era nos tempos de ouro do capitalismo burocrático. Assim é que se pode entender os silêncios sobre o Administrador como profissional de carreira e também o aspecto performático, este último como uma alternativa para mostrar-se ainda necessário. Os sujeitos se mostram como pretensos Administradores, tentando apresentar discursivamente trajetórias profissionais que façam algum sentido em substituição ou alternativa à carreira gerencial, esta que não se lhes apresenta mais como possibilidade, exemplificando o eu maleável, a colagem de fragmentos em incessantes ensaios do vir a ser, de que fala Sennett (2007), ao qualificar o trabalhador em tempos de flexibilidade.

Finalmente, explicitando os conteúdos discutidos agora em termos dos pares categóricos dialéticos que nortearam toda a pesquisa, um segundo movimento de síntese crítica é proposto para reflexão. Quanto ao par dialético história-naturalização, percebe-se na narrativa o predomínio do discurso que naturaliza diversos fenômenos que, diferentemente, são históricos em sua constituição. Pela frequência das metáforas sistêmicas orgânicas utilizadas pelos entrevistados e que são igualmente abundantes na literatura mainstream revisada, identifica-se a ideológica naturalização de fenômenos sociais como, por exemplo, as organizações e o trabalho que acontece nas mesmas. Naturalizando discursivamente a empresa capitalista, que foi o tipo organizacional mais evocado pelos sujeitos, eles, por conseguinte, também naturalizam tudo o que acontece no âmbito e entorno dela.

É assim, por exemplo, que eles tomam como natural e legitimam o fenômeno da mudança empresarial, mesmo que esta lhes atinja como profissionais. É nessa linha de compreensão que os entrevistados tendem a narrar as empresas a partir do discurso das necessidades e desenvolvimento, tal qual um organismo vivo que necessita de recursos para sua sobrevivência e crescimento. A partir das necessidades empresariais naturalizadas, justifica-se que tudo o que ela demanda, em razão das suas finalidades, seja naturalmente atendido, conforme exemplificado pela concepção pragmática-instrumental. Uma contradição é que estando a Administração e os Administradores atrelados ao desenvolvimento da organização, ao mesmo tempo em que se tornam promotores da ideologia empresarial, sendo por vezes seus principais agentes, eles também são reféns ou atingidos por essa mesma ideologia, em suas novas versões. Tal compreensão traz implicações práticas para a vida dos próprios sujeitos, como bem exemplificam seus silêncios ou fugas do exercício profissional.

Semelhantemente, o par dialético práxis-sistema emerge envolto em contradições, na narrativa totalizante. Os entrevistados repetem o discurso metafórico sistêmico harmonizador para explicar o cotidiano organizacional incluindo, por exemplo, a dimensão da experiência. Nesse sentido, ao contrário da experiência emergir como possibilidade de uma práxis social autêntica e espontânea, ela se desvela como práxis inautêntica, posto que tomada de maneira coisificada para atender à demanda pragmática-instrumental da organização; isto é, a experiência é evocada por eles como algo que se adquire para uso instrumental, em lugar de algo que se vive com potencial emancipatório, além de estar associada à localização sistêmica do Administrador. Eles são administradores na medida em que se confinam "funcionalisticamente" na organização-sistema. Fora dela, não parece haver, para eles, a possibilidade da experiência autêntica como administradores. Será este também outro motivo das novas rotas profissionais que traçam, como professores e empreendedores, em lugar de Administradores profissionais? Em outro sentido, ao se refletir sobre a concepção estética com que apresentam o Administrador que ainda reside nos territórios da organização, não estaria também a necessidade de mostrar, de ser visto, de aparecer perante o outro, obliterando a possibilidade de uma práxis social autêntica? 
Consequentemente, essas reflexões permitem, também, concluir que, no que concerne ao par dialético emancipação-alienação, tanto a forma naturalizada com que concebem as organizações e sua Administração, quanto a práxis interrompida velada em uma experiência reificada, mostram-se como fenômenos pessoalmente alienantes e contra-emancipatórios.

Por outro lado, percebe-se na aparente fuga da profissão uma tentativa dos sujeitos de resolverem o que vulgarmente chama-se de "esquizofrenia constituinte" da Administração: o fato de a Administração ser trabalho, mas ter de "pensar-se" como capital, para poder ser o trabalho que interessa e serve ao capital. Os entrevistados resolvem tal questão como que dizendo: se a grande empresa muda e não posso mais gozar da recompensa pelo status anteriormente garantido enquanto representante do capital, prefiro, agora, sair dos seus domínios. Se antes eu não me assumia como trabalho por ser vantajoso pensar e agir como se fosse capital, cumprindo o papel da mediação, agora que o status de tal condição já não me é garantido, adoto uma rota de fuga ou de solução para tal condição contra-emancipatória: agora eu sou outro trabalho, preferencialmente na esfera pública (a docência sendo o mais escolhido), ou sou realmente capital (entre os entrevistados já proprietários e os que almejam o futuro negócio próprio); estando esta última opção fortemente imbricada no atual e efusivo discurso do empreendedorismo, que a todos alcança e é reproduzido como se o empreendedorismo individual fosse, desde sempre, a "ordem natural" das coisas.

Neste movimento de fuga discursiva, os entrevistados parecem (re)significar o silêncio fundador da alienação associada à condição de Administrador: o de não se assumir como trabalho, mantendo-se historicamente como representante do capital. Entende-se aqui que as possibilidades de emancipação desse profissional guardam relação com tal processo de tomada de consciência, mesmo em tempos de riscos e incertezas. Assumindo-se como trabalhador, o Administrador poderá lutar pelo seu trabalho, repensando-o em novos termos, em que as dimensões pragmáticas-instrumentais que envolvem sua profissão possam ser dosadas e mediadas por conteúdos substantivos e emancipatórios. Dado que o estranhamento parece ter lhe "custado caro", assumir sua real condição pode ser um bom (re)começo.

\section{Considerações Finais}

Este texto baseou-se em uma pesquisa cujo objetivo foi compreender criticamente as concepções de Administração e Administrador, na contemporaneidade, a partir das mudanças promovidas pelo capitalismo em sua fase flexível. Ao primeiro objetivo específico - identificar as concepções do campo administrativo sobre a Administração, em tempos de capitalismo flexível -, a pesquisa de campo responde com o predomínio da concepção pragmática-instrumental, pela qual a Administração continua a ser pensada e discursada como uma ação tecnológica e teleológica, que utiliza saberes múltiplos e aprendizagens cambiantes como meios para alcance das finalidades do contexto organizacional mutante. Ao segundo objetivo específico - identificar as concepções do campo administrativo sobre o Administrador, em tempos de capitalismo flexível -, a pesquisa traz dois importantes resultados. O primeiro diz respeito à emergência da concepção estética para apresentar o Administrador, quando vinculado às organizações. Por essa concepção, há a migração do histórico estereótipo do Administrador como controlador e vigilante para a representação do Administrador como um profissional performático muito associado à figura do líder. O segundo resultado, que se apresenta como o mais relevante, e que, portanto, enseja maiores investigações para melhor compreensão, é o da fuga da profissão.

Do ponto de vista da escolha do objeto e das decisões metodológicas decorrentes, percebe-se como uma escolha acertada ter investigado as concepções sobre os dois construtos de maneira interligada: Administração e Administrador; incitando os sujeitos, com um mix de técnicas qualitativas, a se colocarem diante do construto Administrador a partir de suas próprias existências. Entende-se, ao final dessa pesquisa, que se a mesma tivesse se limitado a tentar compreender o que é a Administração para esses sujeitos, sem trazer o construto Administrador para o "centro da cena", não teria, por exemplo, emergido a aparente contradição da repetição da Administração como matéria pragmática-instrumental acompanhada, agora, da fuga disso por parte dos Administradores. Semelhantemente, era possível que a dimensão estética não 
emergisse como qualificadora desse profissional, na atualidade. Assim, nessa pesquisa, foi possível "experienciar" e reafirmar um pressuposto básico da pesquisa qualitativa que é por vezes esquecido: os sujeitos expressam o que pensam e sentem sobre qualquer tema quando lhes é oportunizado falar a partir de suas próprias existências e suas projeções sobre elas. Cabe aos pesquisadores qualitativos buscar com afinco e rigor, mas sem rigidez, formas criativas de fazê-lo.

Uma outra contribuição foi de natureza teórica, ou mesmo didática. Trata-se do levantamento das concepções de parte da literatura predominante na área, pelo menos ao nível de graduação, sobre seus principais construtos, através dos resultados socializados de maneira sintética na segunda parte do trabalho. Ao mesmo tempo que foi uma contribuição, compreende-se que tal levantamento abre uma possibilidade de linha de investigação para novos estudos que considerem pertinente investigar as concepções dos construtos fulcrais do campo administrativo, subjacentes ao discurso do seu próprio mainstream. Nesse estudo, foi interessante identificar que foram os próprios autores do management que começaram a "acabar discursivamente com a área", e não os autores críticos do capital. Autores considerados "gurus" do campo, que compõem o seleto grupo dos mais lidos, foram os primeiros propagadores do discurso do fim da Administração como profissão. Será que as falas condenatórias e "apocalípticas" de Drucker, Champy e Deming sobre a Administração têm sido reproduzidas por outros autores do mainstream? Seria interessante verificar.

Outra possibilidade de temática para novos estudos é a da empregabilidade de Administradores sobre o capitalismo flexível, no contexto de pequenas, médias e grandes empresas. Parece haver uma demanda ainda reprimida sobre tal tema que pode ser suprida com estudos longitudinais a médio e longo prazos, visando entender o que se apresenta, no mercado de trabalho, para essa categoria profissional, em termos de quantidade e perfil dos postos de trabalho. Será que as vagas para Administradores graduados seguem a lógica de um local esvaziado, ou com sentido modificado, como socializado pelos sujeitos dessa pesquisa?

Finalmente, esse texto propõe a continuidade do exercício crítico da reflexividade sobre seus temas; logo, apresenta-se aos leitores como um convite à interlocução, lembrando:

Todo texto é uma máquina preguiçosa pedindo ao leitor que faça uma parte de seu trabalho. Que problema seria se um texto tivesse de dizer tudo que o receptor deve compreender...

Umberto Eco

\section{Referências}

ADORNO, T. W. Introdução à controvérsia sobre o Positivismo na sociedade alemã. In: HORKHEIMER, M. et al. Textos Escolhidos. São Paulo: Abril Cultural, 1980. 117-154 p. (Col. Os pensadores).

ADORNO, T. W. Sobre a lógica das Ciências Sociais. In: COHN, G. Theodor W. Adorno. São Paulo: Editora Ática, 1986. 46-61 p. (Col. Grandes Cientistas Sociais).

ADORNO, T. W. Introdução à sociologia. São Paulo: UNESP, 2008.

ADORNO, T.; HORKHEIMER, M. (1947). Dialética do esclarecimento: fragmentos filosóficos. Rio de Janeiro: Jorge Zahar Ed., 1985.

AKTOUF, O. Ensino de Administração: por uma pedagogia para a mudança. Revista Organizações e Sociedade, Salvador, v. 12, n. 35, p. 151-159, out./dez. 2005.

ALBANDES-MOREIRA, L. A. An exploratory study on the nature of the representations of organization, manager and management within a group of teachers of a business school. 2002. $280 \mathrm{f}$. Tese (Doutorado em Administração) - École des Hautes Études Commerciales, Montreal, Quebec, 2002. 
ALVENSON, M.; DEETZ, S. Teoria Crítica e abordagens pós-modernas para Estudos Organizacionais. In: CLEGG, S. R.; HARDY, C.; NORD, W. (Org.). Handbook de Estudos Organizacionais. v. 1. São Paulo: Atlas, 1998.

ANTUNES, R. Os sentidos do trabalho: ensaio sobre a afirmação e a negação do trabalho. São Paulo: Boitempo, 2003.

BERNARDO, J. Democracia totalitária: teoria e prática da empresa soberana. SP: Cortez, 2004.

BICALHO, R. A. Das histórias de violências em uma empresa júnior à reprodução da ideologia da administração. Dissertação de Mestrado Acadêmico em Administração. Universidade Federal de Minas Gerais, Belo Horizonte, 2009.

BICALHO, R. A.; PAES DE PAULA, A. P. Empresa júnior e a reprodução da ideologia da Administração. In: II Encontro de Ensino e Pesquisa em Administração e Contabilidade (EnEPQ) da Associação Nacional dos Cursos de Pósgraduação em Administração (ANPAD), 2009, Curitiba. Anais... Curitiba, 2009. 1 CD-ROM.

BITTENCOURT NETO, E. O mal-estar da gerência. In: III Encontro de Estudos Organizacionais da Associação Nacional dos Cursos de Pós-graduação em Administração (ANPAD), 2004, Atibaia-SP. Anais... Atibaia-SP, 2004.

BOLTANSKI, L.; CHIAPELLO, E. O novo espírito do capitalismo. São Paulo: WMF Martins Fontes, 2009.

BRAVERMAN, H. Trabalho e capital monopolista: a degradação do trabalho no século XX. 3. ed. Rio de Janeiro: Ed. Guanabara, 1987.

BROCKLEHURST, M.; GREY. C.; STURDY, A. Management: the work that dares not speak its name. Management Learning, London, v. 41, n. 1, p. 7-19, 2009.

CARDOSO, M. F. Vigilância eletrônica no trabalho bancário: do controle consentido ao totalitarismo corporativo. 2010. 148 f. Dissertação (Mestrado Acadêmico em Administração) - Universidade Federal do Rio Grande do Norte, Natal, 2010.

CASTRO, C. M. A profissionalização do administrador e o amadorismo dos cursos. Revista de Administração de Empresas, v. 14, n. 2, p. 59-66, mar./abr. 1974.

CHAMPY, J. Reengenharia da gerência: o mandato da nova liderança. Gerenciando a mudança na reengenharia. Rio de Janeiro: Campus, 1995.

CHANDLER JR, A. D. The emergence of managerial capitalism. The business history review. v. 58, n. 4, p. 473-503, 1984.

CHANDLER JR, A. D. Strategy and structure: chapters in the history of the American Industrial Enterprise. Cambridge, Massachusetts: The Mit Press, 1962.

COVRE, M. L. M. A formação e a ideologia do administrador de empresa. 2. ed. Petrópolis: Vozes, 1982.

DEMING, E. Qualidade: a revolução da Administração. RJ: Marques-Saraiva, 1990.

DESLAURIERS, J. P.; KÉRISIT, M. O delineamento da pesquisa qualitativa. In: POUPART, J. et al. A pesquisa qualitativa: enfoques epistemológicos e metodológicos. Rio de Janeiro: Vozes, 2008. 127-153 p.

DRUCKER, P. Administração: tarefas, responsabilidades, práticas. SP: Pioneira, 1975.

FARIA, J. H. Tecnologia e processo de trabalho. Curitiba: Editora UFPR, 1992.

FARIA, J. H. Economia política do poder: fundamentos. v. 1. Curitiba: Juruá, 2004a.

FARIA, J. H. Economia política do poder: as práticas do controle nas organizações. v. 3. Curitiba: Juruá, 2004 b.

FAYOL, H. Administração industrial e geral: previsão, organização, comando, coordenação, controle. 10. ed. São Paulo: Atlas, 1989. 
GAULEJAC, V. Gestão como doença social: ideologia, poder gerencialista e fragmentação social. São Paulo: Ideia e Letras, 2007.

GOMES, R. A análise de dados em pesquisa qualitativa. In: MINAYO, M. C. S. (Org.). Pesquisa social: teoria, método e criatividade. Rio de Janeiro: Vozes, 1996.

GREY, C. Management as a technical practice: professionalization or responsibilization? Systems Practice, v. 10, n. 6 , p. 703-725, 1997.

GREY, C. We are all managers now; we always were: on the development and demise of management. Journal of Management Studies, v. 36, n. 5, p. 561-585, sept. 1999.

HAGUETTE, T. M. F. Metodologias qualitativas na sociologia. Petrópolis: Vozes, 2001.

HORKHEIMER, M. Teoria Tradicional e Teoria Crítica. In: HORKHEIMER, M. et al. Textos escolhidos. São Paulo: Abril Cultural, 1980, 117-154 p. (Col. Os Pensadores).

JAY, M. Imaginação dialética. História da Escola de Frankfurt e do Instituto de Pesquisas Sociais. 1923-1950. Rio de Janeiro: Contraponto Editora, 2008.

JOVCHELOVITCH, S.; BAUER, M. W. Entrevista narrativa. In: GASKELL, G. Pesquisa qualitativa com texto, imagem e som. Petrópolis: Vozes, 2002.

LAKOFF, G.; JOHNSON, M. Metáforas da vida cotidiana. Campinas-SP: Mercado de Letras; São Paulo: Educ., 2002 .

MILLS, C. W. A nova classe média. 3 ed. Rio de Janeiro: Zahar Ed., 1979.

MINAYO, M. C. S. Hermenêutica-Dialética como caminho do pensamento social. In: MINAYO, M. C. S.; DESLANDES, S. F. Caminhos do pensamento: epistemologia e método. Rio de Janeiro: Editora Fiocruz, 2002.83 $107 \mathrm{p}$.

MINAYO, M. C. S. O desafio do conhecimento: pesquisa qualitativa em saúde. 8. ed. São Paulo: Hucitec / Rio de Janeiro: Abrasco, 2004.

MINTZBERG, H. Managing. São Francisco-CA: Berrett-Koehler Publishers, 2009.

MORGAN, G. Imagens da organização. São Paulo: Atlas, 1996.

MOTTA, F. C. P. Teoria das Organizações: evolução e crítica. 2. ed. São Paulo: Pioneira Thomson Learning, 2001.

OHNO, T. O Sistema Toyota de Produção. Porto Alegre: Artes Médicas, 1997.

OLIVEIRA, M. M. Metodologia Interativa: um processo hermenêutico-dialético. Revista Interfaces Brasil/Canadá, v. 1, n. 1, p. 67-78, 2001.

PAULA, A. P. P. Guerreiro Ramos: resgatando o pensamento de um sociólogo crítico das organizações. Revista Organizações \& Sociedade, Salvador, v. 14, n. 40, p. 169-188, jan./mar. 2007.

PAULA, A. P. P. Teoria crítica nas organizações. São Paulo: Thomson Learning, 2008.

PEREIRA, L. C. B. O Administrador profissional e as perspectivas da sociedade brasileira. Revista de Administração de Empresas, v. 6, n. 20, p. 88-110, jul./set. 1966.

RAMOS, A. G. A nova ciência das organizações: uma re-conceituação da riqueza das nações. Rio de Janeiro: Editora da Fundação Getulio Vargas, 1981.

RAMOS, A. G. Administração e contexto brasileiro: esboço de uma teoria geral da administração. 2. ed. Rio de Janeiro: Fundação Getulio Vargas, 1983. 
RAYMUNDO, P. R. O que é Administração. Ed. Brasiliense, 2006. (Col. Primeiros Passos).

RICHERS, R. O que é empresa. Editora Brasiliense, 2005. (Col. Primeiros Passos).

SENGE. P. A quinta disciplina. SP: Best Seller, 1990.

SENNETT, R. A corrosão do caráter: as consequências pessoais do trabalho no novo capitalismo. 6. ed. Tradução de Marcos Santarrita. Rio de Janeiro: Record, 2007.

SILVA, A. B. Como os gerentes aprendem? São Paulo: Saraiva, 2009.

STEIN, E. Dialética e Hermenêutica: uma controvérsia sobre método e filosofia. In: HABERMAS, J. Dialética e Hermenêutica. São Paulo: L\&PM, 1987. 98-134 p. (Apêndice).

TAYLOR, F. W. Princípios de administração científica. 7. ed. São Paulo: Atlas, 1986.

WEBER, M. Economia e sociedade: fundamentos da sociologia compreensiva. 3. ed. Tradução de Regis Barbosa e Karen Barbosa. Brasília: Universidade de Brasília, 1994.

Apêndice

Quadro 5

Roteiro de entrevista com elementos de história de vida (Sujeitos: administradores)

\begin{tabular}{|c|} 
Dados de caracterização: \\
Idade - Sexo - Estado Civil - Tempo de formado \\
10 Momento: fase pré-universitária \\
Fale-me um pouco da sua vida estudantil antes de entrar na universidade... \\
Por que Administração? O que te fez, o que te levou a escolher esse curso? \\
20 Momento: fase universitária \\
Fale-me um pouco da sua vida como aluno de Administração... \\
O que você lembra de que mais gostou durante o curso? (disciplinas, estágio etc.) Por quê? \\
O que você lembra de que menos gostou durante o curso? (disciplinas, estágio etc.) Por quê? \\
Fa sua época de formatura, o que você pensava para a sua vida profissional? \\
Fale-me um pouco da sua vida profissional até aqui... \\
O que você pensa para o futuro?
\end{tabular}




\section{Quadro 6}

Roteiro de entrevista com elementos de história de vida (Sujeitos: alunos)

\begin{tabular}{|} 
Dados de caracterização: \\
Idade - Sexo - Estado Civil - Tempo de curso \\
10 Momento: fase pré-universitária \\
Fale-me um pouco da sua vida estudantil antes de entrar na universidade... \\
Por que Administração? O que lhe fez, o que Ihe levou a escolher este curso? \\
2o Momento: fase universitária \\
Fale-me um pouco da sua vida como aluno de Administração... \\
Do que você mais gostou no seu curso até agora? (disciplinas, estágio etc.) Por quê? \\
Do que você menos gostou no seu curso até agora? (disciplinas, estágio etc.) Por quê? \\
3o Momento: fase pós-universitária \\
O que você pensa para a sua vida profissional depois da formatura?
\end{tabular}

\section{Quadro 7}

Roteiro de entrevista com elementos de história de vida (Sujeitos: professores)

Dados de caracterização:
Idade - Sexo - Estado Civil - Tempo de formado
10 Momento: fase pré-universitária
Fale-me um pouco da sua vida estudantil antes de entrar na universidade...
Por que cursar Administração?
20 Momento: fase universitária e pós-universitária
Fale-me um pouco da sua vida estudantil nos tempos de graduando...
For que ensinar Administração?
Como tem sido, para você, ensinar Administração?




\section{Quadro 8}

\section{Roteiro da entrevista ficcional (Sujeitos de pesquisa: administradores, alunos)}

\section{Script:}

É manhã de uma 2å feira do mês de de 2022. Diferente do habitual, você não se dirigiu ao seu local de trabalho. Em lugar disso, você foi a um evento no Centro de Convenções da cidade. No intervalo da 1a palestra, você aproveitou para ir ao restaurante para tomar um café. Para sua surpresa, lá você encontra um(a) ex-professor(a) dos tempos de universidade. Ele(a) também estava participando do evento. Vocês iniciam uma conversa...

\section{Questões de apoio:}

Qual a cidade do evento? / Qual é o evento? Nome? / Quem está promovendo?

Qual é a palestra que você está assistindo? / Quem é esse(a) professor(a)? / Ele(a) foi seu professor(a) em qual disciplina? / Em que ano você terminou o curso? / Como foi a conversa? / O que você falou para ele sobre sua vida profissional desde que se formou? / Fale um pouco dessa(s) experiência(s)...

\section{Quadro 9}

\section{Roteiro da entrevista ficcional (Sujeitos de pesquisa: professores)}

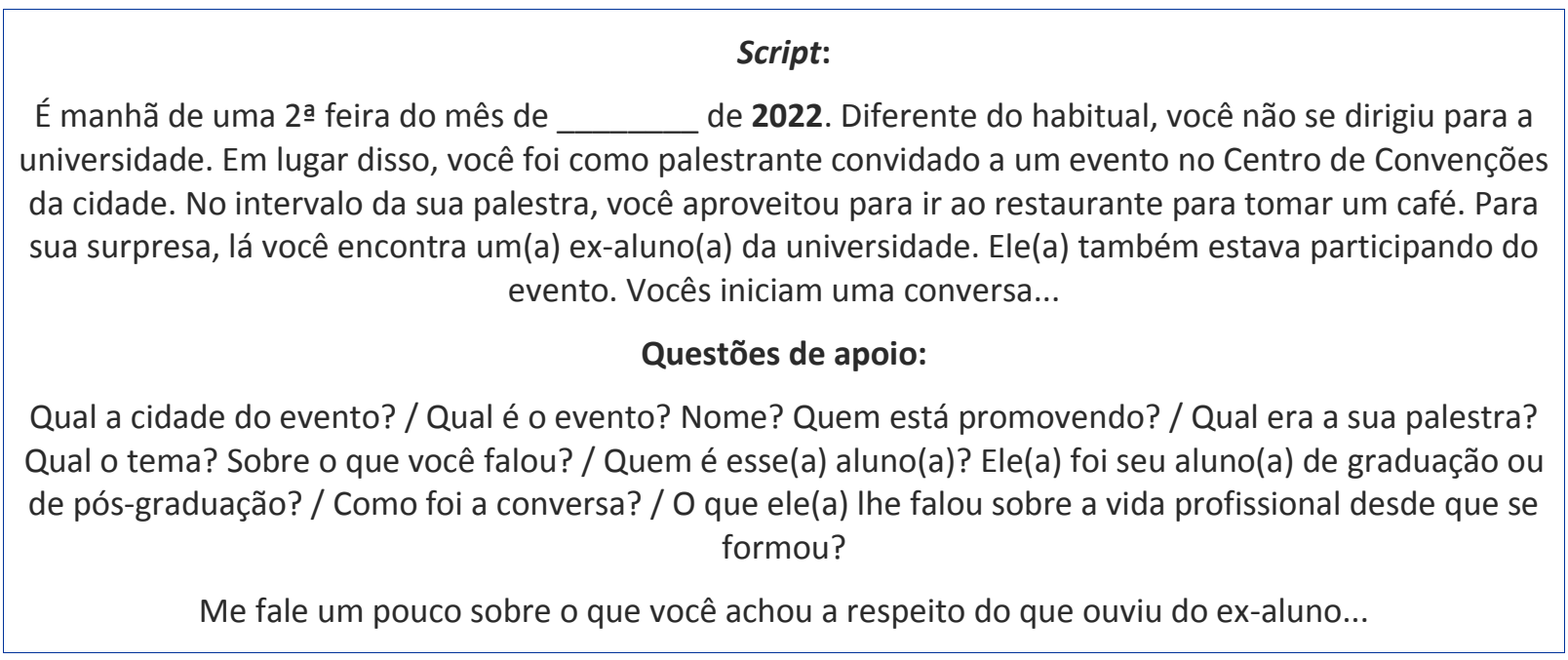

